\title{
Tumor cell entry into the lymph node is controlled by CCL1 chemokine expressed by lymph node lymphatic sinuses
}

\author{
Suvendu Das, ${ }^{1}$ Eliana Sarrou, ${ }^{1}$ Simona Podgrabinska, ${ }^{1}$ Melanie Cassella, ${ }^{1}$ \\ Sathish Kumar Mungamuri, ${ }^{1}$ Nikki Feirt, ${ }^{3}$ Ronald Gordon, ${ }^{2}$ \\ Chandandeep S. Nagi, ${ }^{2}$ Yarong Wang, ${ }^{4}$ David Entenberg, ${ }^{4,5}$ \\ John Condeelis, ${ }^{4,5}$ and Mihaela Skobe ${ }^{1}$
}

\begin{abstract}
'Department of Oncological Sciences and 2Department of Pathology, Icahn School of Medicine at Mount Sinai, New York, NY 10029 ${ }^{3}$ Department of Pathology, Columbia University, New York, NY 10027

${ }^{4}$ Department of Anatomy and Structural Biology and ${ }^{5}$ Gruss Lipper Biophotonics Center, Albert Einstein College of Medicine, Bronx, NY 10461
\end{abstract}

Lymphatic vessels are thought to contribute to metastasis primarily by serving as a transportation system. It is widely believed that tumor cells enter lymph nodes passively by the flow of lymph. We demonstrate that lymph node lymphatic sinuses control tumor cell entry into the lymph node, which requires active tumor cell migration. In human and mouse tissues, CCL1 protein is detected in lymph node lymphatic sinuses but not in the peripheral lymphatics. CCR8, the receptor for CCL1, is strongly expressed by human malignant melanoma. Tumor cell migration to lymphatic endothelial cells (LECs) in vitro is inhibited by blocking CCR8 or CCL1, and recombinant CCL1 promotes migration of CCR8 ${ }^{+}$tumor cells. The proinflammatory mediators TNF, IL-1 $\beta$, and LPS increase CCL1 production by LECs and tumor cell migration to LECs. In a mouse model, blocking CCR8 with the soluble antagonist or knockdown with shRNA significantly decreased lymph node metastasis. Notably, inhibition of CCR8 led to the arrest of tumor cells in the collecting lymphatic vessels at the junction with the lymph node subcapsular sinus. These data identify a novel function for CCL1-CCR8 in metastasis and lymph node LECs as a critical checkpoint for the entry of metastases into the lymph nodes.

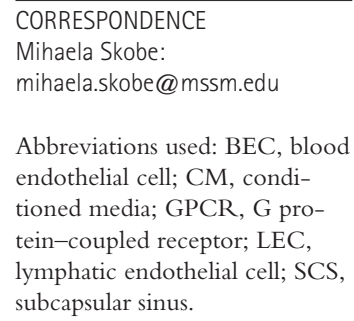

Abbreviations used: BEC, blood endothelial cell; CM, conditioned media; GPCR, G protein-coupled receptor; LEC, lymphatic endothelial cell; SCS, subcapsular sinus.

Metastasis of tumor cells to the regional lymph nodes is one of the key indicators of tumor aggressiveness. Lymph node status is a powerful predictor of patient survival and it is one of the key parameters used for determining the stage of disease progression and treatment options (Greene et al., 2006; Morton et al., 2006). Despite the paramount importance of lymph node status for the patient outcome, the mechanisms by which tumor cells are recruited to the lymph nodes are poorly understood.

According to the current paradigm, once tumor cells gain access to the lymphatic vessels, they are carried with the flow of lymph into the sentinel lymph nodes where they subsequently reside. Entry of tumor cells into the lymphatics has been thought to occur randomly, as a consequence of tumor cell invasion through tissue. However, recent findings indicate that tumor cells are guided into the lymphatic vessels by chemokines produced by lymphatic endothelium (Ben-Baruch, 2008; Das and Skobe, 2008). The CCL21-CCR7 ligand-receptor pair is thought to play a central role in directing tumor cells to the lymph nodes. CCL21 is constitutively expressed by the lymphatic vessels (Gunn et al., 1998; Podgrabinska et al., 2002; Kerjaschki et al., 2004; Shields et al., 2007a), and its receptor CCR7 is expressed by melanoma and breast cancer cells (Müller et al., 2001; Houshmand and Zlotnik, 2003). Overexpression of CCR7 in melanoma has been shown to facilitate tumor metastasis to the lymph nodes in a mouse model (Wiley et al., 2001) and clinical studies have confirmed the association between CCR7

( 2013 Das et al. This article is distributed under the terms of an AttributionNoncommercial-Share Alike-No Mirror Sites license for the first six months Noncommercial-Share Alike-No Mirror Sites license for the first six months
after the publication date (see http://www.rupress.org/terms). After six months it is available under a Creative Commons License (Attribution-NoncommercialShare Alike 3.0 Unported license, as described at http://creativecommons.org/ licenses/by-nc-sa/3.0/). 
expression in tumors and lymph node metastasis (Mashino et al., 2002; Cabioglu et al., 2005; Ishigami et al., 2007). Another chemokine receptor important for metastasis is CXCR4. It is the most widely expressed chemokine receptor in cancer and it has been shown to direct tumor cells to the lung and other distant organs, as well as to the lymph nodes (Müller et al., 2001).

CCR8 is a G protein-coupled receptor (GPCR), which in humans is selectively activated by the CC chemokine CCL1/ I-309 (Roos et al., 1997; Tiffany et al., 1997; Goya et al., 1998). In mice, the novel chemokine CCL8 has recently been identified as a second agonist for CCR8, but no human ortholog has yet been found (Islam et al., 2011). CCR 8 plays a rather unique role in the regulation of immune response. It is preferentially expressed by activated T helper type $2\left(\mathrm{~T}_{\mathrm{H}} 2\right)$ cells (D'Ambrosio et al., 1998; Zingoni et al., 1998; Islam et al., 2011) and it mediates $\mathrm{T}_{\mathrm{H}} 2$ cell recruitment to the sites of inflammation (Chensue et al., 2001; Gombert et al., 2005; Islam et al., 2011). Because $\mathrm{T}_{\mathrm{H}} 2$ cells are primary drivers of allergy and asthma, CCR 8 activation has been implicated in allergic inflammation and pulmonary hypersensitivity (Chensue et al., 2001; Gombert et al., 2005; Islam et al., 2011). Other functions of CCR 8 include T cell homing to skin in the steady state (Schaerli et al., 2004; Ebert et al., 2006), the role in DC migration to the lymph nodes (Miller and Krangel, 1992; Qu et al., 2004), and the role in thymic development (Louahed et al., 2003). Consistent with its role in recruitment of $\mathrm{T}$ cells to tissues, CCL1 is constitutively expressed by dermal blood vasculature (Schaerli et al., 2004; Gombert et al., 2005). In the skin, CCL1 is also expressed by melanocytes and by Langerhans cells but not by keratinocytes (Schaerli et al., 2004; Gombert et al., 2005). Inflammatory cytokines and microbial products dramatically induce CCL1 expression (Gombert et al., 2005).

In cancer, the CCL1-CCR 8 axis has been implicated in leukemia and in lymphoma. The CCL1-CCR8 autocrine loop has been shown to protect lymphoma and T cell leukemia cells from apoptosis in vitro (Van Snick et al., 1996; Ruckes et al., 2001; Louahed et al., 2003) and to play a role in T cell transformation (Tamgüney et al., 2004). Whether the CCL1CCR 8 axis plays a role in solid tumors is not yet known.

Here, we demonstrate a novel function for CCL1-CCR8 in controlling the egress of tumor cells from the afferent lymphatics into the lymph node. We made an unexpected discovery that the lymphatic endothelial cells (LECs) at the junction of the collecting lymphatic vessel and the lymph node represent a barrier for entry of tumor cells into the lymph node. Activation of tumor cell CCR 8 by CCL1, which is produced by LECs of the lymph node subcapsular sinus (SCS), allows entry of tumor cells into the node and subsequent formation of lymph node metastases. These data identify a novel mechanism of regulation of cell entry into the lymph node.

\section{RESULTS \\ Identification of CCL1 as the major tumor cell chemoattractant produced by LECs}

We examined the effects of media conditioned by lymphatic endothelium on the chemotaxis of several human melanoma and breast carcinoma cell lines. LEC-conditioned media (CM) was chemotactic for most metastatic cell lines tested (Fig. 1 A). The highly metastatic cells MDA-MB-435 and SK-MEL-25 showed the highest increase in migration, followed by MCF-7 and MDA-MB-231 cells. In contrast, nontumorigenic human breast epithelial cell lines MCF-10F and 184-B5 and a low metastatic melanoma cell line, MEL-501, did not show a significant increase in chemotaxis in response to LECs. SK-MEL-28 cells did not show increased migration to LEC-CM; however, this cell line has very high basal migration levels (unpublished data) so that increases are difficult to detect. These results indicate that metastatic tumor cells acquire responsiveness to the chemotactic signals derived from the lymphatic endothelium.

The induction of tumor cell chemotaxis by LEC-CM was completely abolished by pretreatment of tumor cells with pertussis toxin, indicating that the chemotactic effect is mediated through GPCRs (Fig. 1 B). We therefore screened for chemokine production by LECs and found that CCL1 mediates much of the chemotactic activity found in the LEC-CM. CCL1 mRNA and protein were constitutively expressed by cultured LECs, as determined by RT-PCR, Western blotting, and ELISA (see Fig. 2, B and D). CCL1 protein was detected in LEC-CM by Western blotting as a heparin-bound fraction. A function-blocking monoclonal antibody to CCL1 reduced chemotaxis of MDA-MB-435 and SK-MEL-25 cells to LECCM by 73 and $60 \%$, respectively (Fig. 1 C). Depletion of CCL1 with a different specific polyclonal antibody reduced tumor cell migration to a similar extent (Fig. 1 D). In agreement, chemotaxis in response to LEC-CM, which was depleted using heparin, showed a decrease of $62 \%$ (unpublished data). Conversely, addition of rhCCL1 showed an increase in tumor cell chemotaxis (Fig. 1 E) but not haptotaxis (unpublished data). CCL1 was not expressed by MDA-MB-435 and SK-MEL-25 cells (see Fig. $5 \mathrm{~A}$ ), indicating its paracrine role in these models. CCL1 had no effect on tumor cell growth or survival in vitro (unpublished data).

Consistent with its function in cell migration, rhCCL1 induced cytoskeletal rearrangements and altered in vitro tumor cell morphology from elongated to round, as determined by F-actin staining (Fig. 1 F). These effects, which are a prerequisite for cell motility (Burger et al., 1999), were transient in nature; first changes were observed at $20 \mathrm{~min}$, the effect was most pronounced at $40 \mathrm{~min}$, and at $60 \mathrm{~min}$ of exposure to CCL1, cell shape largely returned to normal. Collectively, these data identify CCL1 as a potent tumor chemotactic factor produced by LECs.

\section{CCL1 mediates tumor cell migration to inflamed LECs}

Treatment of LECs either with proinflammatory cytokines or with LPS resulted in a dramatic increase of CCL1 mRNA expression (Fig. 2 A). Within 18 h, both TNF and IL-1 $\beta$ increased CCL1 mRNA 543- and 340-fold, respectively, as determined by qPCR. LPS increased CCL1 mRNA expression by 400-fold (Fig. 2 A). ELISA and Western blot analysis of the CM collected from LECs treated with TNF, IL-1 $\beta$, or 

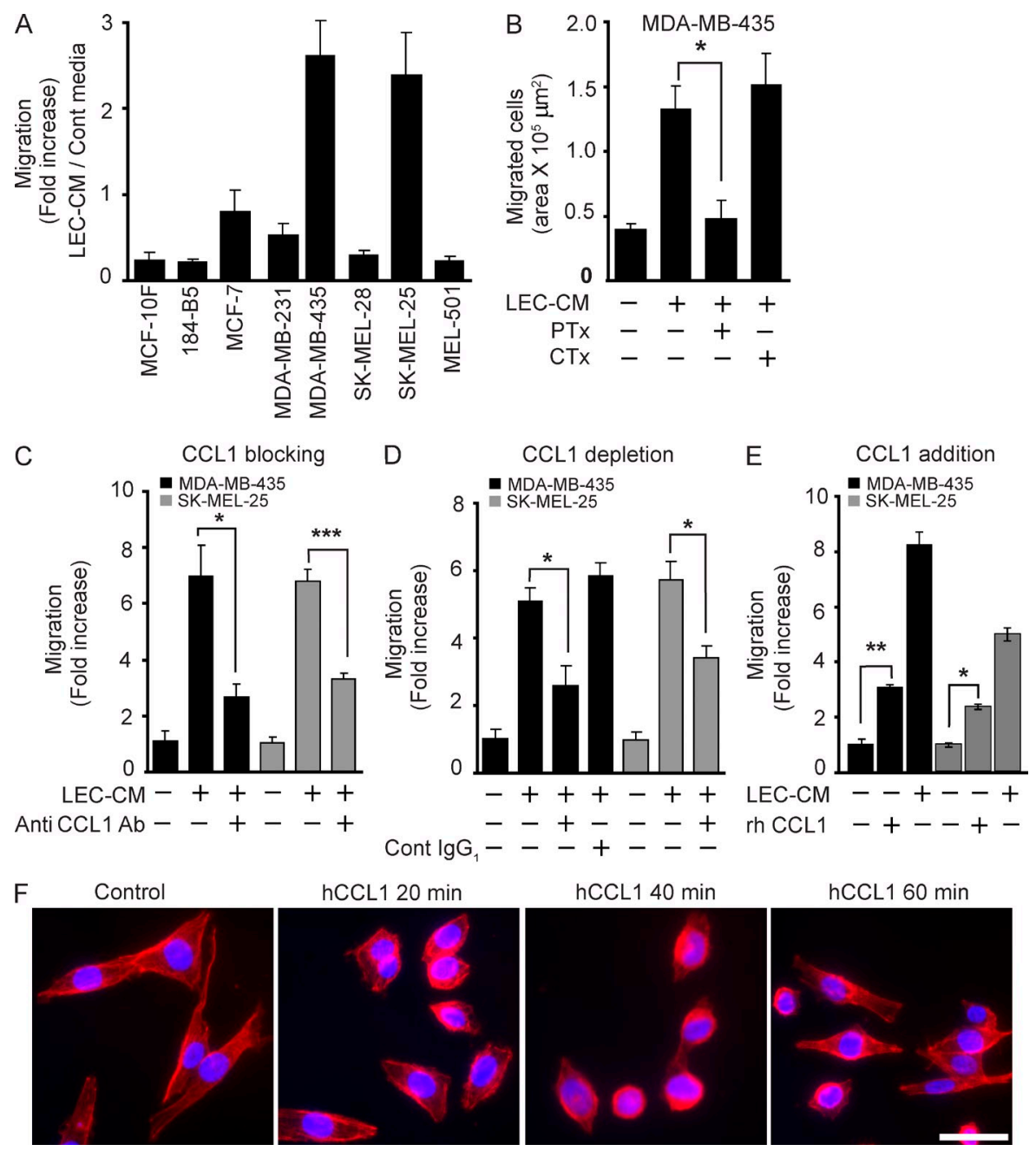

Figure 1. Tumor cell chemotaxis to LECs is mediated by CCL1. (A) Migration of breast cancer and melanoma cells to LEC-CM in a Boyden chamber assay. MCF-10F and 184-B5, nontumorigenic human breast epithelial cell lines; MCF-7, MDA-MB-231, and MDA-MB-435, breast cancer cell lines; SK-MEL-28, SK-MEL-25, and MEL-501, melanomas. (B) Migration of MDA-MB-435 cells to LEC-CM in presence of pertussis toxin (PTx) or cholera toxin (CTX). (C) Effects of a monoclonal anti-CCL1 neutralizing antibody on MDA-MB-435 and SK-MEL-25 chemotaxis to LEC-CM. (D) Tumor cell migration to LEC-CM depleted of CCL1 with a polyclonal anti-CCL1 antibody. (E) Migration of tumor cells to $50 \mathrm{ng} / \mathrm{ml}$ rhCCL1, in comparison to LEC-CM. (F) Cell shape change of MDA-MB-435 cells stimulated with $50 \mathrm{ng} / \mathrm{ml}$ human CCL1. Cells are stained with rhodamine-labeled phalloidin (red) and Hoechst (nuclei; blue). Data are representative of three experiments. Migration (fold increase) is calculated as cell migration (total cell area) to LEC-CM/cell migration to basal medium. Error bars indicate SD, $n=3 .{ }^{*}, \mathrm{P}<0.05 i^{* *}, \mathrm{P}<0.01 ;{ }^{* *}, \mathrm{P}<0.001$. Bar, $10 \mu \mathrm{m}$.

LPS showed increased amounts of the secreted CCL1 protein (Fig. 2, C and D). CCL1 protein levels were also increased by serum (unpublished data).

CM collected from LECs treated with TNF or LPS stimulated tumor cell chemotaxis to an even greater extent than CM obtained from untreated LECs ( $\sim 12$-fold vs. 8-fold increase, respectively; Fig. 2, E and F). Increased tumor cell chemotaxis to inflamed LECs was completely abolished by depleting CCL1 (Fig. 2, E and F). Neither TNF nor LPS had a direct effect on tumor cell migration (unpublished data) indicating that proinflammatory cytokines facilitate tumor cell migration indirectly by up-regulating CCL1 expression in LECs.

In agreement with the in vitro data, CCL1 protein was strongly up-regulated on lymphatic vessels in mouse skin upon treatment with TNF or application of FITC (Fig. 2, G-L). CCL1 protein was also strongly up-regulated on dermal lymphatic vessels in human foreskins treated ex vivo with TNF but was not detectable on dermal lymphatics of normal mouse skin (Fig. 2, G and H) or human skin (not depicted) by immunostaining. Collectively, these data demonstrate that proinflammatory stimuli strongly up-regulate CCL1 expression in vitro and in vivo.

\section{Tumor cell lines express functional CCR8 receptor}

Human CCL1 binds to and exclusively activates CCR8 (Roos et al., 1997; Tiffany et al., 1997; Goya et al., 1998). We examined the expression of CCR 8 by the tumor cells that responded to CCL1 with increased migration (Fig. 3 and see Fig. 5). 

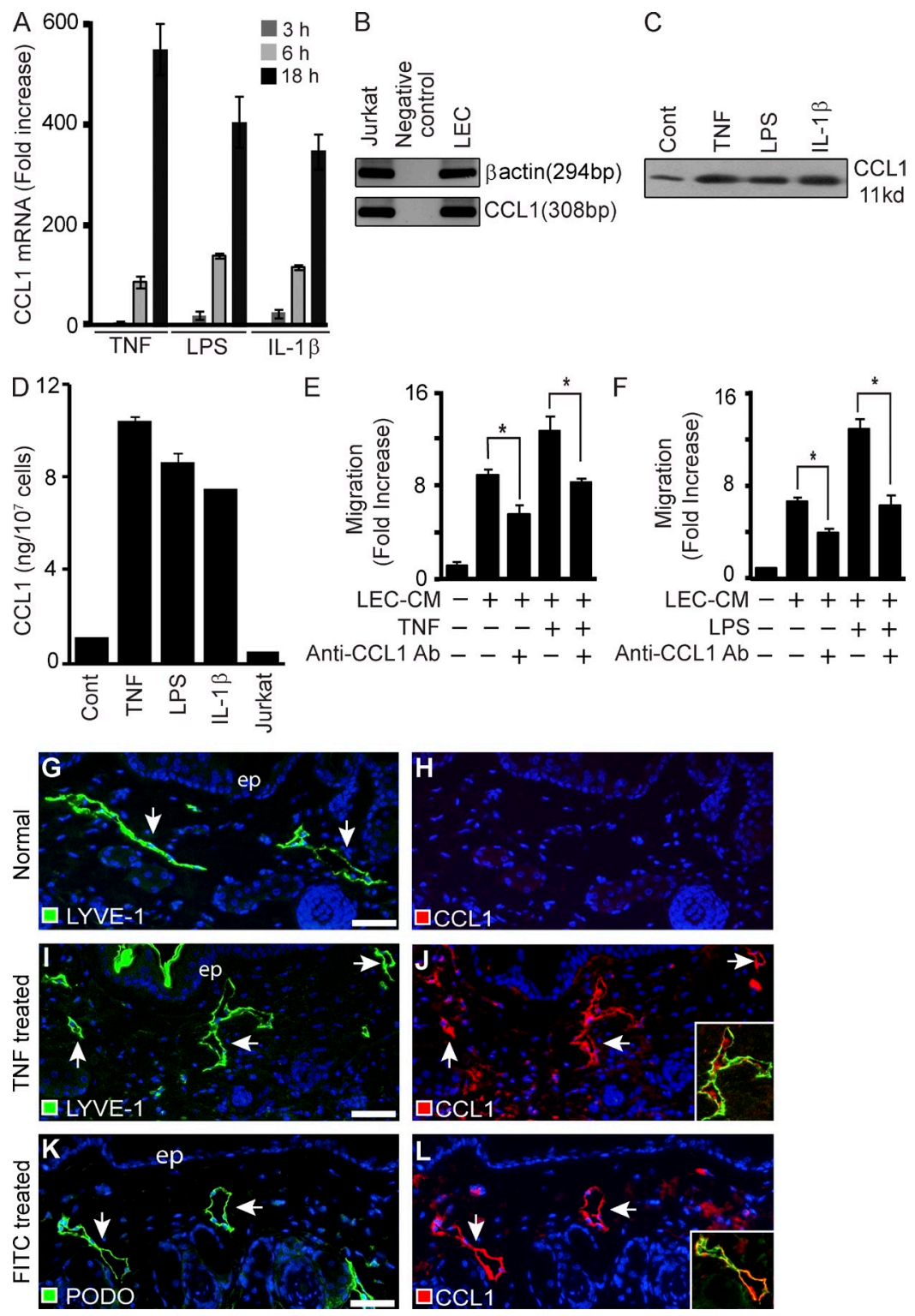

Figure 2. Inflammatory cytokines increase CCL1 production by LECs and tumor cell migration to LEC-CM. (A) Real-time qPCR analysis for CCL1 mRNA upon treatment of LECs with $50 \mathrm{ng} / \mathrm{ml} \mathrm{TNF}, 500 \mathrm{ng} / \mathrm{ml} \mathrm{LPS}$, or $50 \mathrm{ng} / \mathrm{ml} \mathrm{IL-1 \beta}$ for 3, 6 , and $18 \mathrm{~h}$. Error bars indicate mean \pm SD, $n=3$. (B) RT-PCR for CCL1 mRNA expression in cultured LECs. CDNA from PMA-stimulated Jurkat cells ( $50 \mathrm{ng} / \mathrm{ml}, 48 \mathrm{~h}$ ) was used as a positive control. (C and D) Western blot (C) and ELISA (D) for CCL1 protein in conditioned medium from LECs treated with $100 \mathrm{ng} / \mathrm{ml} \mathrm{TNF}, 500 \mathrm{ng} / \mathrm{ml} \mathrm{LPS}$, or $50 \mathrm{ng} / \mathrm{ml} \mathrm{IL-1 \beta}$ for $48 \mathrm{~h}$, and CM from Jurkat cells treated with $50 \mathrm{ng} / \mathrm{ml}$ PMA for $48 \mathrm{~h}$. Error bars indicate mean $\pm \mathrm{SD}, n=2$. (E and F) Effects of CCL1 depletion on tumor cell (MDA-MB435) migration to LEC-CM generated in presence of $50 \mathrm{ng} / \mathrm{ml}$ TNF (E) or $500 \mathrm{ng} / \mathrm{ml}$ LPS (F) for $48 \mathrm{~h}$. Bars indicate mean $\pm S D, n=3$. Data are representative of three experiments. ${ }^{*}, \mathrm{P}<0.05$. (G-L) Immunostaining of mouse skin for either LYVE-1 or podoplanin (both green) and for CCL1 (red); boxed areas in $J$ and $L$ depict the overlay. Images are representative of at least six skin samples per group. Arrows, lymphatic vessels; ep, epidermis. Bars, $50 \mu m$.

SK-MEL-25 and MDA-MB-435 cells expressed CCR8 mRNA, as determined by RT-PCR (Fig. $3 \mathrm{~A}$ and see Fig. 5 A). Western blot analysis showed expression of CCR 8 protein by both tumor cell lines in vitro and in vivo, and this was further confirmed by FACS (Fig. 3, A and B; and see Fig. 5 B). Primary melanocytes did not show any detectable levels of CCR 8 by FACS (Fig. 3 B).

To determine whether CCR 8 mediates cell migration, we examined the effects of MC148, a specific CCR8 antagonist, on chemotaxis of tumor cells to LEC-CM. MC148 is a highly selective CCR 8 antagonist derived from the human poxvirus Molluscum contagiosum, which binds to CCR 8 with the same affinity as its endogenous ligand CCL1 (Lüttichau et al., 2000). Preincubation of the tumor cells with MC148 potently blocked tumor cell migration (Fig. $3 \mathrm{C}$ ), indicating that CCR 8 mediates most of the chemotactic response to LEC-CM. MC148 also prevented the cytoskeletal rearrangements and cell shape change of tumor cells (MDA-MB-435) 

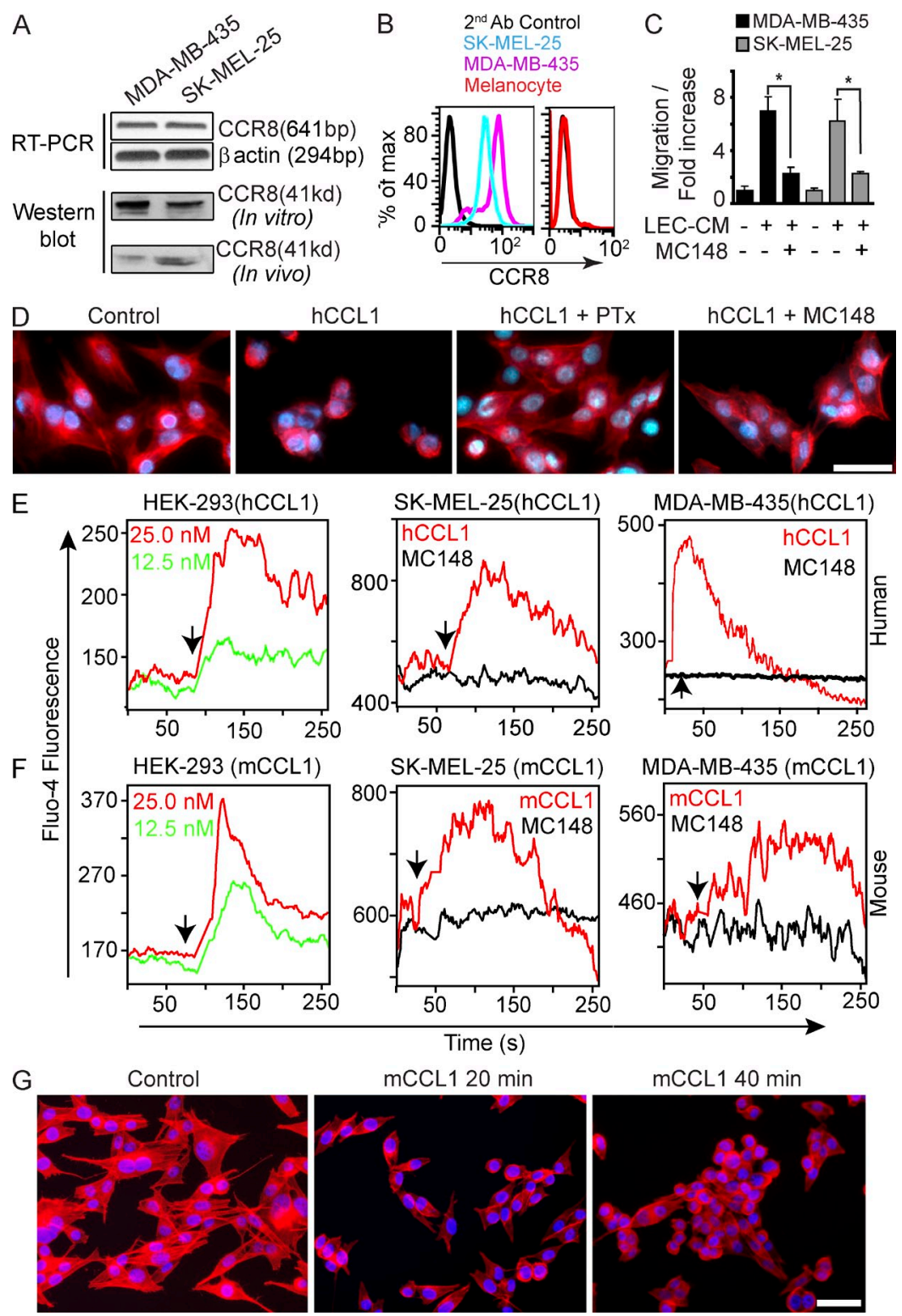

Figure 3. CCR8 expression and function in tumor cell lines. (A) Expression of CCR8 mRNA (RT-PCR, in vitro) and protein (Western blot, in vitro and in vivo) by MDA-MB-435 and SK-MEL-25 cells. (B) FACS analysis was performed on cultured tumor cells and primary melanocytes. (C) Effects of CCR8 antagonist MC148 on tumor cell chemotaxis to LEC-CM. Error bars indicate mean \pm SD, $n=3$. ${ }^{*}, P<0.05$. (D) Effects of CCR8 antagonist MC148 and pertussis toxin (PTX) on cytoskeletal rearrangements induced by rhCCL1 in MDA-MB-435 cells. Cells are stained with phalloidin (red) and Hoechst (nuclei, blue). Data are representative of three experiments. ( $\mathrm{E}$ and F) Changes of cytosolic $\mathrm{Ca}^{2+}$ concentration measured by FACS in Fluo-4-labeled cells upon addition of human (E) or mouse (F) CCL1 (12.5 or $25 \mathrm{nM}$ as indicated). The black arrow indicates the time of CCL1 addition. MC148 was added at $25 \mathrm{nM}$. Data are expressed as percentile fluorescence intensity of Fluo-4 dye bound to $\mathrm{Ca}^{2+}$. Data are representative of at least two experiments. (G) Cell shape change of MDA-MB-435 cells stimulated with $50 \mathrm{ng} / \mathrm{ml}$ mouse CCL1 for the times indicated. Cells are stained with rhodamine-labeled phalloidin (red). Bars, $10 \mu \mathrm{m}$.

stimulated with rhCCL1, and the effect was comparable to that of pertussis toxin, a broad inhibitor of GPCR signaling (Fig. 3 D). These data demonstrate that CCL1 mediates its effects on tumor cell migration by activating CCR 8 and GPCR signaling in tumor cells.

Chemoattraction induced by chemokines is associated with a transient rise in intracellular calcium after receptor activation, a hallmark of GPCR-mediated signal transduction
(Houshmand and Zlotnik, 2003). To further assess the functionality of CCR 8 expressed by human tumor cells, we measured intracellular calcium flux upon the addition of human rCCL1 to three cell lines: SK-MEL-25 and MDA-MB-435 cells, which endogenously express CCR8; and HEK293 cells, which were transfected to overexpress CCR8 (Fig. 3 E). Treatment of cells with rhCCL1 led to a rapid increase in the intracellular calcium level. MC148 completely inhibited 

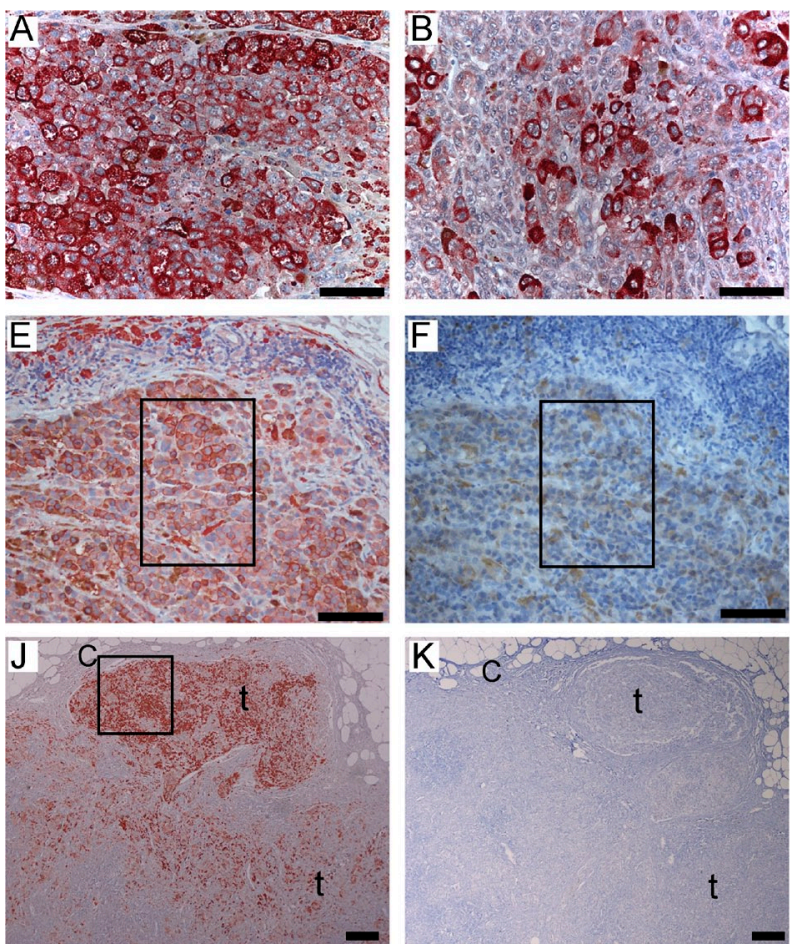
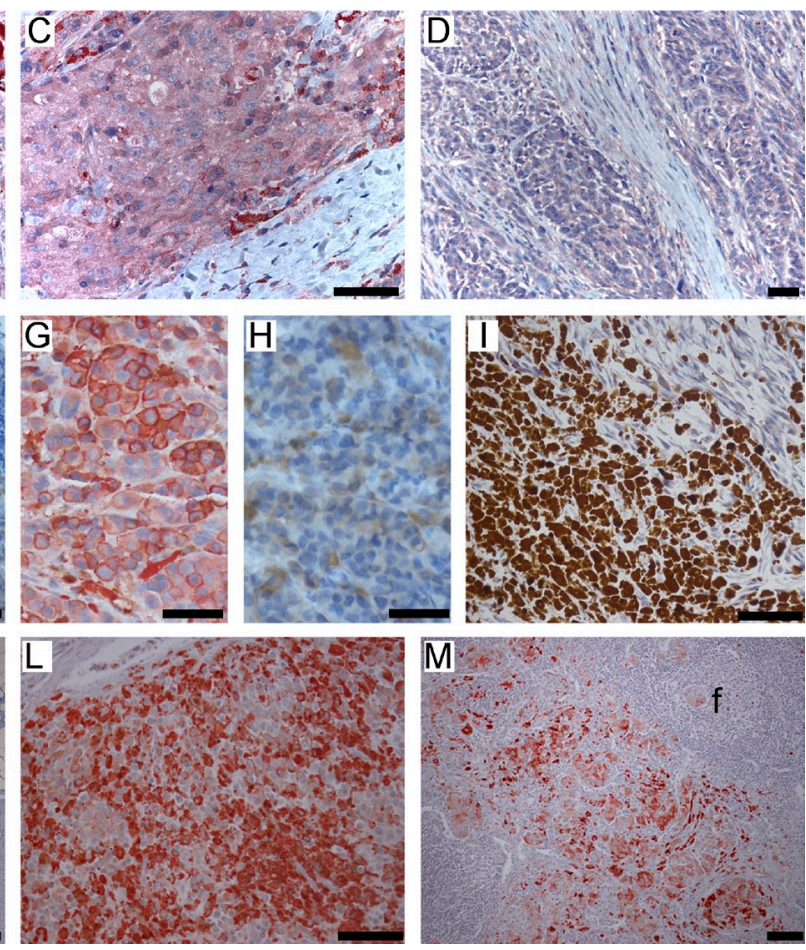

Figure 4. CCR8 expression in human malignant melanoma. Immunohistochemistry for CCR8 (red) on human melanoma tissue array (A-D), samples of primary melanomas in the skin (E-I), and melanoma metastases in the human lymph node (J-M). Tumors showed various staining patterns for CCR8: membrane (A and B), cytoplasmic (C), or no staining (D). (E-H) Serial sections of human melanoma in the skin immunostained for CCR8 (E and G), or secondary antibody control (F and $\mathrm{H})$. (G and H) Higher magnification of the boxed area in E and F. CCR8, red; endogenous melanin, brown. (I) Highly pigmented melanoma negative for CCR8. (J-L) Metastatic melanoma localized in the subcapsular zone of the lymph node stained for CCR8 (J and L) or secondary antibody control (K) on the serial sections. (L) Higher magnification of the boxed area in J. (M) CCR8 expression in metastatic melanoma localized in the follicular zone of the lymph node. Images are representative of 87 primary tumors and 8 lymph node samples. c, capsule; $t$, tumor; $f$, follicle. Bars: ( $\mathrm{J}$ and $\mathrm{K}) 200 \mu \mathrm{m} ;(\mathrm{A}-\mathrm{F}, \mathrm{I}, \mathrm{L}$, and $\mathrm{M}) 100 \mu \mathrm{m} ;(\mathrm{G}$ and $\mathrm{H}) 25 \mu \mathrm{m}$.

influx of $\left[\mathrm{Ca}^{2+}\right]$ induced by rhCCL1, but in the absence of CCL1, MC148 had no effect on $\left[\mathrm{Ca}^{2+}\right]$ mobilization.

Because it has not been unequivocally demonstrated that mouse CCL1 activates human CCR8, we also performed calcium flux studies upon addition of mouse CCL1 to human cells (HEK-293, SK-MEL-25, and MDA-MB-435; Fig. 3 F). Recombinant mouse CCL1 rapidly increased intracellular calcium level, whereas the CCR8 antagonist MC148 completely inhibited mCCL1-induced $\left[\mathrm{Ca}^{2+}\right]$ flux. Similar to human CCL1, mouse CCL1 also induced cytoskeletal rearrangements in MDA-MB-435 cells (compare Fig. $3 \mathrm{G}$ to Fig. 1 F). These data establish mouse CCL1 as an agonist for human CCR8.

\section{CCR8 is expressed in human metastatic melanoma}

We examined the expression of CCR 8 by immunohistochemistry on a tissue array containing 90 cases of human malignant melanomas, in another cohort of 19 samples of human melanoma in the skin, and in 8 lymph nodes with melanoma metastases. Analysis of the tissue array showed CCR 8 expression in $71 \%$ of the samples at variable levels of intensity (Fig. 4, A-D). Approximately half of the positive samples (34\%) showed strong membrane staining. Some melanomas showed intense staining for CCR8 throughout the specimen, whereas others showed a focal pattern of expression (Fig. 4, A and B). Melanomas showing weak or moderate levels of CCR 8 mostly exhibited homogenous cytoplasmic staining (Fig. 4 C).

Analysis of a different cohort of patient samples $(n=19)$ also showed that CCR 8 is expressed in melanoma; 18/19 samples (95\%) stained positive for CCR 8 , whereas 11/19 samples $(57 \%)$ were strongly positive (Fig. 4, E-I). Melanin distribution in the tumor did not overlap with the CCR8 expression pattern and amelanotic melanomas also expressed CCR8. In the lymph nodes, seven out of eight metastases were positive for CCR8 (Fig. 4, J-M). In accordance with the in vitro data, melanocytes in the skin did not express the CCR 8 receptor. Lymphatic vessels in the normal or tumor-associated skin were CCR 8 negative. A subset of blood vessels (arterioles) was CCR 8 positive, in agreement with the published data (Haque et al., 2004). A small subset of tumor-infiltrating lymphocytes in the skin and in the lymph nodes was also CCR 8 positive (unpublished data).

\section{Blocking CCR8 inhibits lymph node metastasis}

To examine the role of CCR 8 in tumor metastasis, we transfected three tumor cell lines to constitutively express either the MC148 soluble antagonist or a CCR 8 shRNA: 


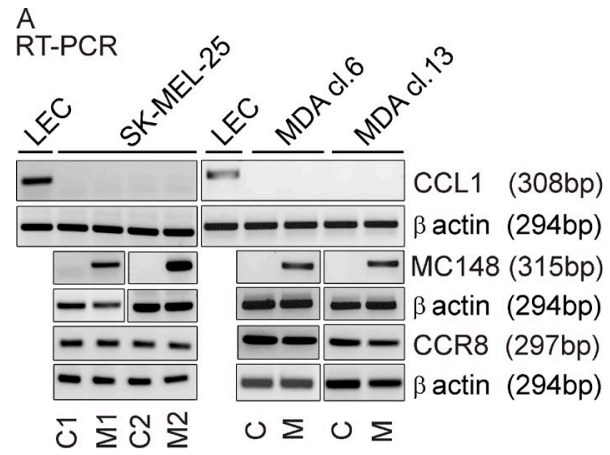

Bestern blot

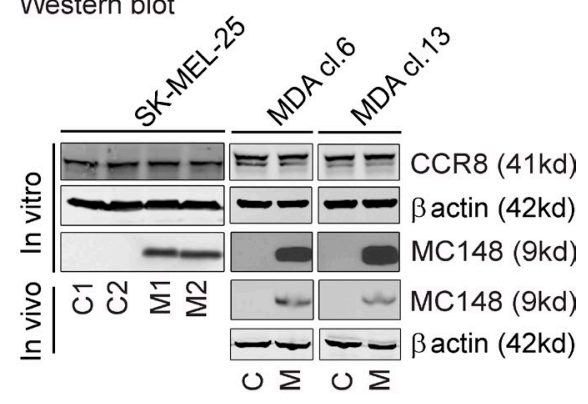

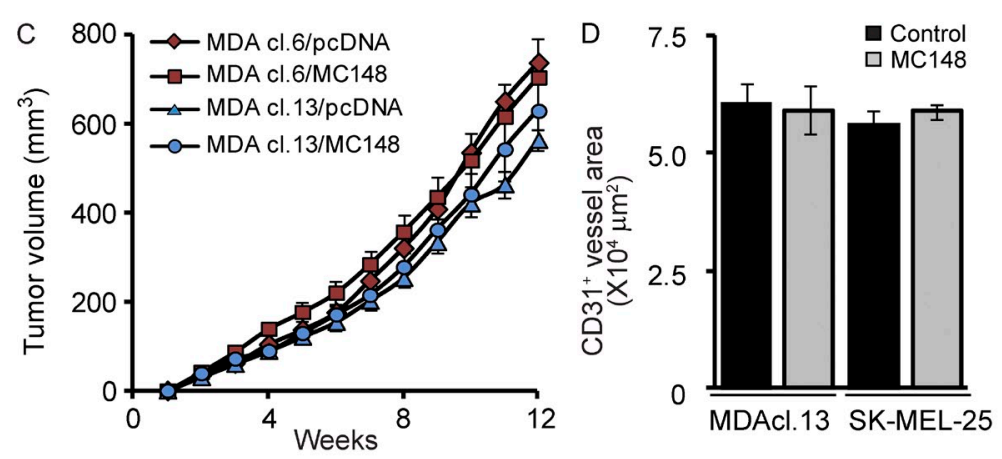
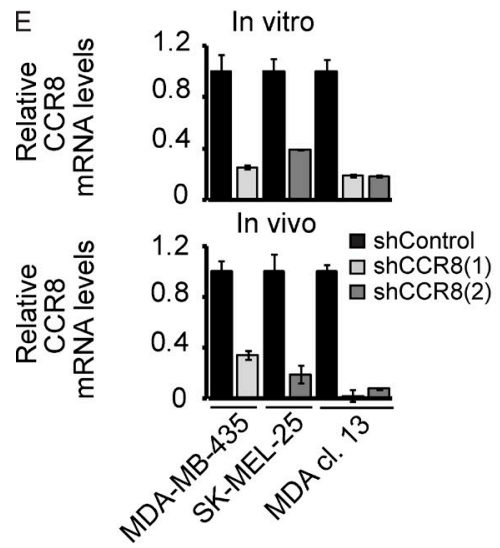

$\mathrm{F}$

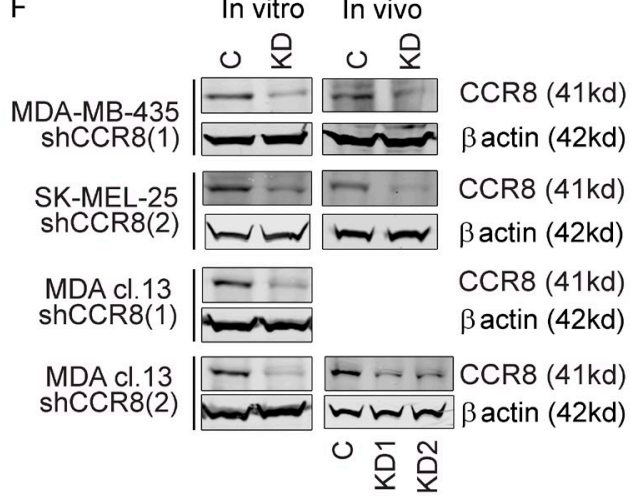

\begin{tabular}{|c|c|c|c|c|c|}
\hline Cell line & pcDNA & MC148 & shControl & shCCR8(1) & shCCR8(2) \\
\hline SK-MEL-25 & $6 / 14(42 \%)$ & $0 / 18(0 \%)^{\star \star \star}$ & $10 / 14(71 \%)$ & ND & $0 / 12(0 \%)^{\star \star \star}$ \\
\hline MDA-MB-435 & $7 / 20(35 \%)$ & $2 / 20(10 \%)^{n s}$ & $7 / 14(50 \%)$ & $2 / 14(14 \%)^{\mathrm{ns}}$ & ND \\
\hline MDA cl.13 & $14 / 18(78 \%)$ & $4 / 20(20 \%)^{\star \star \star}$ & $14 / 21(67 \%)$ & $2 / 18(11 \%)^{\star \star \star *}$ & $2 / 18(11 \%)^{\star \star *}$ \\
\hline
\end{tabular}

Figure 5. Blocking CCR8 inhibits lymph node metastasis. (A and B) Expression of CCR8 inhibitor MC148 in tumor cell lines as indicated. (A) RT-PCR of cultured tumor cells for hCCL1, MC148, and hCCR8 mRNA. CDNA from LECs served as a positive control for CCL1. $\beta$-Actin served as a loading control. (B) Western blot for hCCR8 protein in lysates of cultured cells, MC148 protein in tumor cell CM in vitro, and MC148 in tumor lysates in vivo. $\beta$-Actin served as a loading control. C, pcDNA vector control; M, MC148. (C) Tumor growth of pcDNA control and MC148-expressing MDAcl.6 or MDAcl.13 cells. Each data point represents mean tumor volume \pm SEM, $n=10$ mice per group. (D) Quantification of total vessels (CD31 $1^{+}$) in tumors as indicated. Bars represent the mean vessel area \pm SEM per $10^{6} \mu \mathrm{m}^{2}$ total area; MDAcl.13, $n=4 ;$ SK-MEL-25, $n=3$ tumors. (E and F) Efficiency of shRNA-mediated CCR8 knockdown in tumor cells. qPCR for human CCR8 (E) and Western blot analysis (F) in different tumor cell lines in vitro and in tumors in vivo, as indicated. (F) CCR8 knockdown in MDA-MB-435 cells was performed with shCCR8 sequence 1, shCCR8(1); in SK-MEL-25 with the sequence 2, shCCR8(2); and in MDA cl. 13 with shCCR8 sequences 1 and 2. Error bars indicate mean $\pm S D, n=3$. (G) Incidence of intranodal metastases upon CCR8 inhibition with the MC148 soluble antagonist or upon CCR8 knockdown with shRNA. Metastasis incidence is calculated as the number of LN with GFP+ tumor cells, divided by the total number of LN examined. ND, not determined; ns, not significant; ${ }^{* *}, \mathrm{P}<0.001$.

(1) SK-MEL-25 melanoma cells, (2) a highly metastatic subclone of MDA-MB-435 cells, which expresses VEGF-C (MDAcl.13), and (3) parental MDA-MB-435 cells (MDAcl.6; Skobe et al., 2001b; Roberts et al., 2006; Das et al., 2010). Expression of
MC148 mRNA and protein was confirmed by RT-PCR and Western blotting, respectively (Fig. 5, A and B). High levels of MC148 protein were detected in the CM of transfected cells as well as in tumor lysates. MC148 expression did 

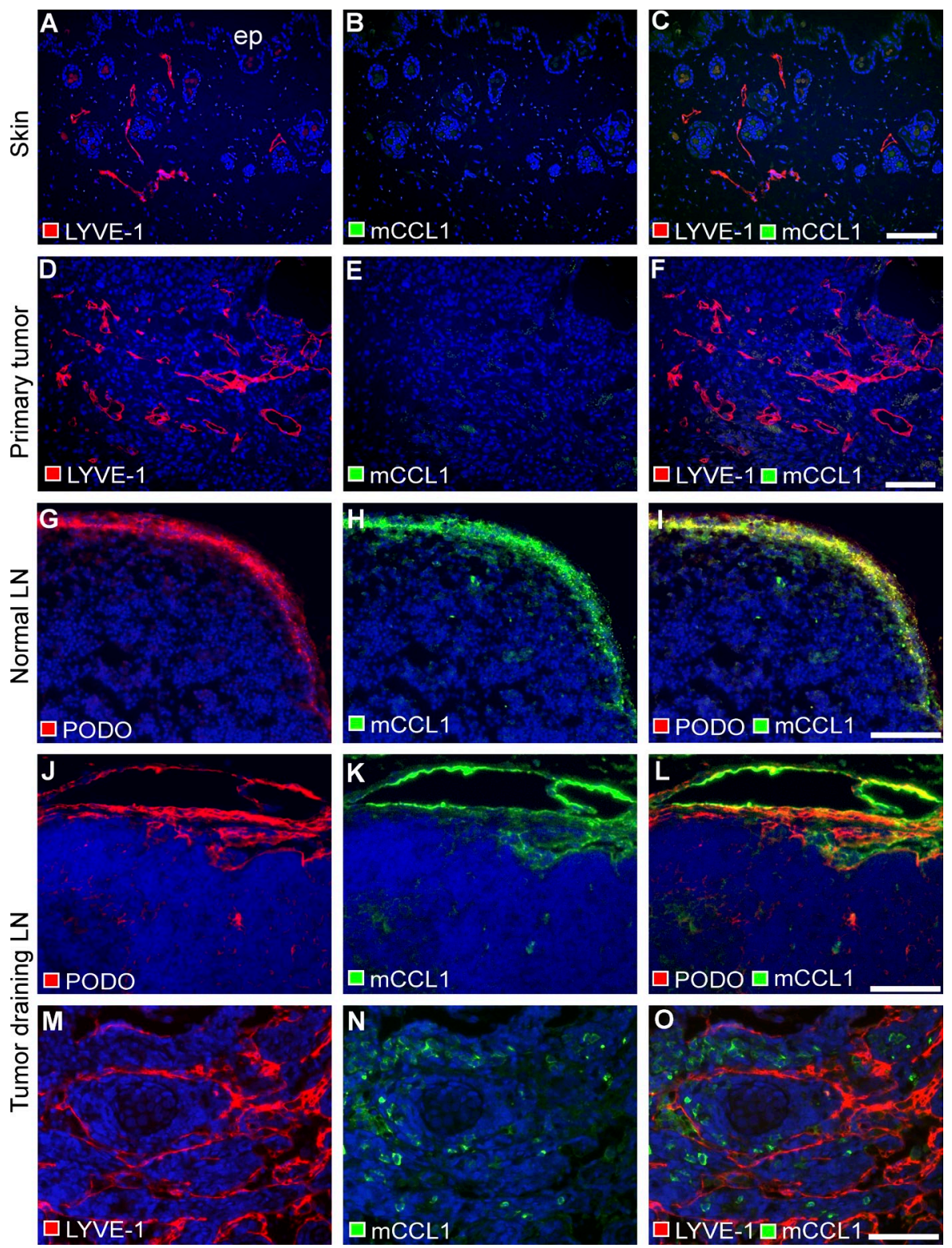

Figure 6. Expression of CCL1 in the mouse skin, tumor, and lymph node lymphatic vessels. (A-0) Double immunostaining for either LYVE-1 or podoplanin (lymphatic vessels, red) and mouse CCL1 (green). (A-C) Mouse skin overlying the tumor. (D-F) MDAcl.13 tumor xenograft. (G-L) Capsule and the lymph node cortex of the naive $(\mathrm{G}-\mathrm{I})$ and the tumor-draining $(\mathrm{J}-\mathrm{L})$ lymph node. (M-0) Lymph node medullary sinuses staining negative for CCL1. Images are representative at least $n=5$ samples per group. ep, epidermis. Bars, $100 \mu \mathrm{m}$.

not change levels of endogenous CCR8 and it did not alter tumor growth of any of the three cell lines in mice or in vitro (Fig. 5, A-C; and not depicted). CCR8 knockdown with shRNA was confirmed in vitro and in vivo by qPCR and by Western blotting (Fig. 5, E and F).

Notably, inhibition of CCR8 with MC148 significantly reduced the incidence of lymph node metastases (Fig. 5 G), as determined by fluorescence microscopy. In the SK-MEL-25 tumor model, metastasis to sentinel lymph nodes was decreased from $42 \%$ in the parental cells to $\%$ in the MC148expressing cells. In the MDAcl.13 model, incidence of lymph node metastases was $78 \%$ in the control versus $20 \%$ in mice bearing MC148-expressing tumors. MDAcl.6 parental tumors showed a $35 \%$ incidence of lymph node metastases in the control group and 10\% in the MC148 transfectants. Furthermore, knockdown of CCR 8 in vivo using two independent shRNA constructs also significantly reduced lymph node metastases, yielding results very similar to those obtained with the MC148 inhibition approach (Fig. 5 G).

Examination of primary tumors for angiogenesis and other histopathological parameters did not reveal major differences between the control and treated groups in any of the tumor models (Fig. 5 D and not depicted). Intratumoral lymphangiogenesis, which was induced only in MDAcl.13 tumors 
(Skobe et al., 2001a; Roberts et al., 2006), was not altered with MC148 or with the shRNA knockdown (unpublished data).

Together, these findings demonstrate that inhibition of CCR8 leads to a significant reduction of lymph node metastases. Because none of the tumor cell lines expressed the CCR8 ligand CCL1 (Fig. 5 A), these data suggested that CCR8 on tumor cells is activated by host-derived CCL1.

\section{CCL1 is expressed by the lymph node SCSs}

Because CCL1 induced tumor cell chemotaxis in vitro and because it was highly up-regulated by inflammatory stimuli in vitro and in vivo, we hypothesized that CCL1 may be expressed by tumor-associated lymphatic vessels and facilitate tumor cell entry into the lymphatics at the primary tumor site. Surprisingly, we could not detect CCL1 in the lymphatic capillaries associated with the primary tumors in mice (Fig. 6). Neither intratumoral lymphatics nor lymphatics in the skin overlying tumors were positive for CCL1 by immunostaining (Fig. 6, A-F). Other stromal cells were also negative for CCL1. Unexpectedly, CCL1 was detected mainly in the SCSs of the lymph nodes, specifically on the lymphatic endothelium of the SCS which was VEGFR-3 $3^{\text {high }}$ / Podoplanin high $/$ LYVE-1 ${ }^{\text {low }}$ (Fig. 6, G-L; and not depicted). The staining pattern of CCL1 in the tumor draining lymph nodes and in the naive LN was similar, indicating constitutive expression. CCL1 was immunostained without permeabilization and it was clearly present on the luminal side of the vessels, indicating that it is displayed on the cell surface (Fig. 6, J-L; and Fig. 2, I-L). Medullary sinuses (VEGFR-3 $3^{\text {high } / ~}$ Podoplanin low/LYVE-1 $1^{\text {high; }}$ not depicted) were negative for CCL1, and only occasionally a few lymphocytes stained positive (Fig. 6, M-O).

Chemokine CCL8 has been recently identified in mice (but not in humans) as a second agonist for CCR8 (Islam et al., 2011). We therefore examined mouse tissues for the presence of CCL8 protein by immunostaining. Tumors and lymph nodes were negative for CCL8, whereas CCL8 protein was detected in skin keratinocytes, consistent with the previous findings (Islam et al., 2011). CCL8 was not detected in the lymphatic vessels in the skin, tumors, or lymph nodes (unpublished data).

The localization of CCL1 in mouse and in human tissues was very similar (Fig. 7). In normal human skin, CCL1 was detected by immunostaining in only a small subset of blood vessels but not in dermal lymphatics (Fig. 7, A and B). In human melanoma, CCL1 was also detected in a subset of blood vessels, and occasionally in tumor cells (unpublished data), but not in the lymphatic vessels (Fig. 7, C-F). In the lymph nodes with melanoma metastases, lymphatic endothelium of the SCSs was positive for CCL1 (Fig. 7, G-J). In addition, a small subset of lymphocytes and a small fraction of blood vessels were also CCL1 positive. These results suggested that the CCL1-CCR8 interaction is not required for tumor cell entry into the lymphatic capillaries and that the CCR8mediated tumor cell interaction with LECs occurs downstream from the primary tumor.
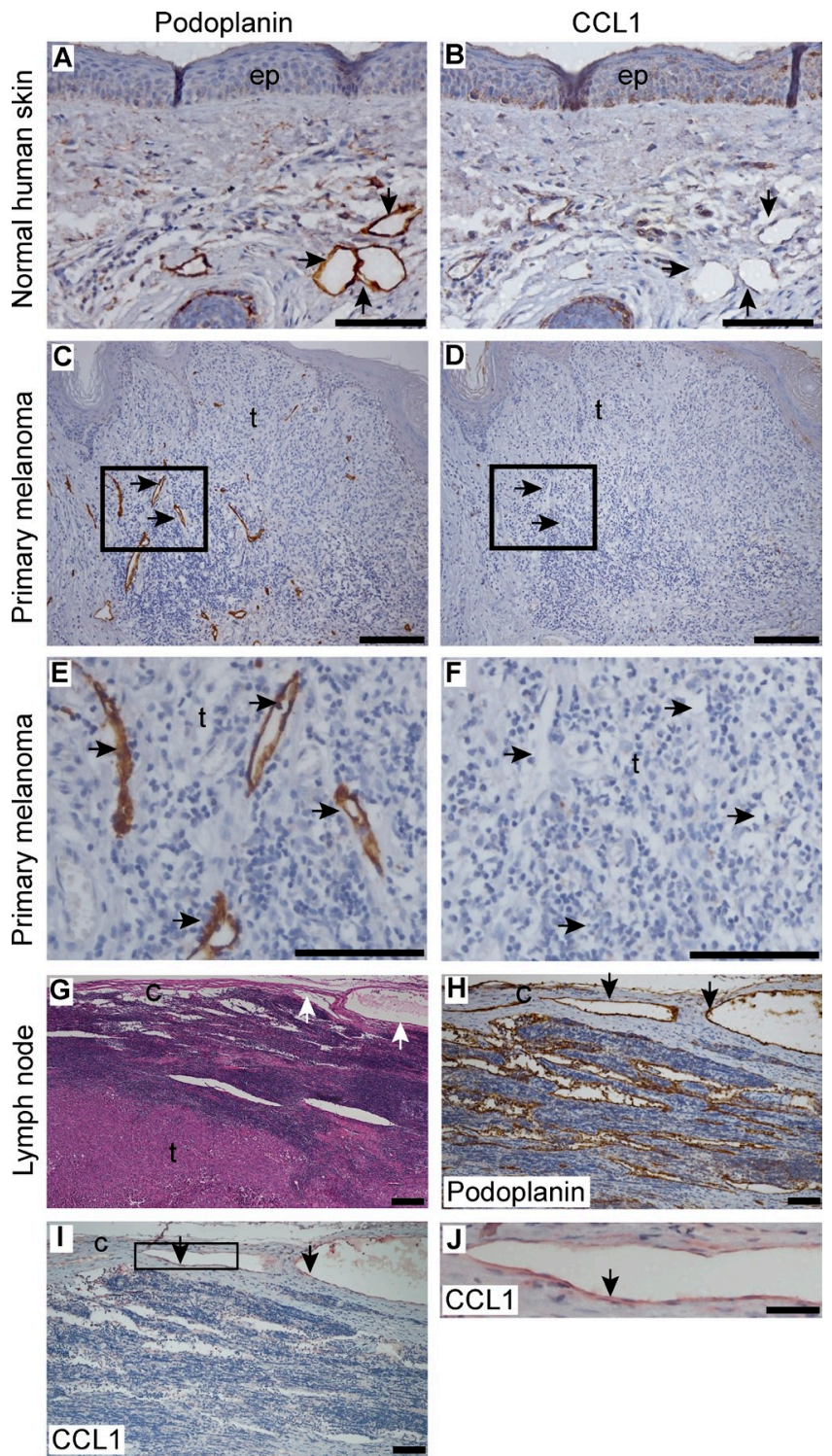

Figure 7. CCL1 expression in human tissues. Immunohistochemical staining for podoplanin (lymphatic vessels) and for human CCL1 on serial sections of normal human skin (A and B), melanoma in the skin (C-F), and lymph nodes with melanoma metastases ( $\mathrm{G}-\mathrm{J})$. ( $\mathrm{E}$ and $\mathrm{F})$ Higher magnification of the boxed area in C and D. (G-J) Serial sections of human lymph node with melanoma metastases stained with $\mathrm{H} \& \mathrm{E}(\mathrm{G})$ or immunostained for podoplanin (H) or CCL1 (I and J). (H) Podoplanin identifies lymphatic vessels of the SCS (arrows) and lymphatics associated with melanoma metastases in the cortex. (I) CCL1 staining (red, arrows) on a serial section. (J) Higher magnification of the boxed area in I. Images are representative of at least 10 skin samples, 14 primary tumors, and 8 lymph node samples. Arrows, lymphatic vessels; t, tumor; ep, epidermis; c, capsule. Bars: (A-F, $H_{1}$ and I) $100 \mu \mathrm{m}$; (G) $250 \mu \mathrm{m}$; (J) $25 \mu \mathrm{m}$.

Blocking CCR8 arrests metastases in the afferent lymphatic vessels and inhibits tumor cell entry into the lymph node

Because we identified the SCS of the lymph node as a main site of CCL1 production, we examined in more detail the characteristics of metastases within the lymph node and at the 

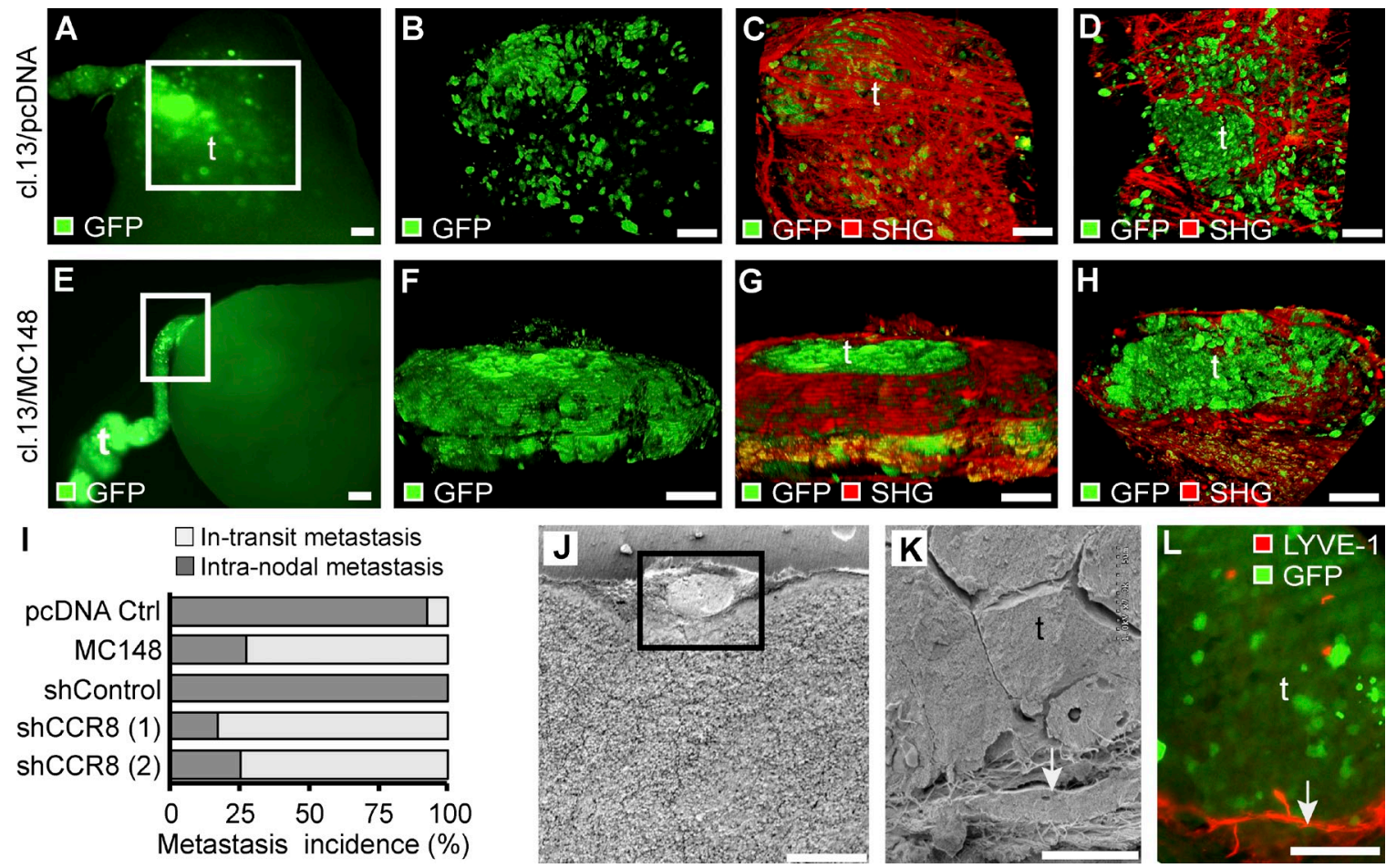

Figure 8. Blocking CCR8 inhibits tumor cell entry into the lymph node from collecting lymphatics. (A-D) Metastases from control, pcDNA empty vector transfected MDAcl.13 cells (GFP, green) in the sentinel lymph nodes. (A) Stereomicroscope captured epifluorescent image of the intact lymph node showing metastases in the afferent lymphatic vessel and inside the lymph node parenchyma (boxed area). (B-D) Ex vivo multiphoton imaging of GFP-labeled metastases (green) combined with second harmonic generation (SHG, red), showing metastases scattered throughout the lymph node cortex. (B and C) View from the top of the lymph node (from the outside). (D) View from the lymph node parenchyma (from the inside). SHG visualizes collagen fibers in the lymph node capsule (red). (E-H) Metastases from MDAcl.13/MC148 tumors. (E) Stereomicroscope captured epifluorescent image showing metastasis in the afferent lymphatic vessel (in-transit metastasis) but not in the lymph node parenchyma. Junction of the lymphatic vessel and the lymph node is sharply demarcated, indicating tumor cell arrest at that location (boxed area). (F-H) ex vivo multiphoton images of metastases (GFP, green) in the afferent lymphatic vessel combined with SHG (red), which visualizes collagen fibers of the lymphatic vessel wall. ( $F$ and $G$ ) Lateral view of the vessel. (H) View into the vessel lumen.

(I) Bar graph depicts the incidence of intranodal metastases and in-transit metastases by MDAcl.13 tumors upon inhibition of CCR8 with MC148 or upon down-regulation with shRNA. Incidence is calculated as percent of all samples positive for either intranodal or in-transit metastases ( $p c D N A$ control, $n=15$; MC148, $n=15$; sh control, $n=14$; shCCR8(1), $n=12$; shCCR8(2), $n=8$ ). (J) Scanning electron microscopy micrograph of a lymph node cross section showing MDAcl.13/shCCR8(1) metastasis in the lymphatic vessel at the junction with the SCS (boxed area); similar site as depicted in E. (K and L) Lymphatic endothelium at the floor of the SCS bordering the tumor visualized by scanning electron microscopy at high magnification (K) or by immunofluorescent staining for LYE-1 (L). Images are representative of at least $n=9$ mice per group. Arrows, lymphatic endothelium; t, tumor. Bars: (A-H, J, and L) $100 \mu m ;(K) 5 \mu m$.

lymph node interface. Remarkably, the sentinel lymph nodes of MDAcl.13/MC148 tumors were mostly free of metastases; however, large clusters of metastatic cells were present in the afferent lymphatic vessels leading to the lymph node (Fig. 8). In the MDAcl.13/MC148 group, metastases were arrested at the junction of the afferent lymphatic vessel and the lymph node, and this border was sharply demarcated (Fig. 8 E). Analysis of the junction by scanning electron microscopy and by immunostaining for lymphatic endothelial markers showed that LECs were the cellular boundary at which the tumor was arrested (Fig. 8, J-L). The collecting lymphatic vessels were greatly distended, particularly in the proximity of the lymph node, and large tumor clusters were seen attached to the luminal wall of lymphatic vessels. In most cases metastases resided in the collecting lymphatics over long distances.

This presence of metastases in the afferent lymphatic vessels away from the primary tumor, but before the regional lymph node basin, is referred to as in-transit metastasis (Balch et al., 2001; Pawlik et al., 2005; van Deurzen et al., 2008). Inhibition of CCR 8 with MC148, or by knockdown with shRNA, increased the ratio of in-transit to intranodal metastases (Fig. 8 I). In the MDAcl.13 control group, 93\% of the mice with metastases were lymph node positive and only $7 \%$ presented with in-transit metastases. In contrast, when the CCR 8 antagonist was expressed, this ratio was reversed; as many as $73 \%$ presented with in-transit metastases, whereas only $27 \%$ had intranodal metastases (Fig. 8 I). Knockdown of CCR 8 using two different shRNA constructs confirmed these results (\% in-transit metastases: control $0 \%$ vs. shCCR $8(1)$ $83 \%$ vs. shCCR $8(2) 75 \%$; Fig. 8 I). In the MDA-MB-435 parental and SK-MEL-25 tumor models the trend was similar; however, these tumors did not induce lymphangiogenesis and therefore did not have as high a metastatic burden in the lymphatic vessels as MDAcl.13 tumors. In the MDAcl.6 tumors, 

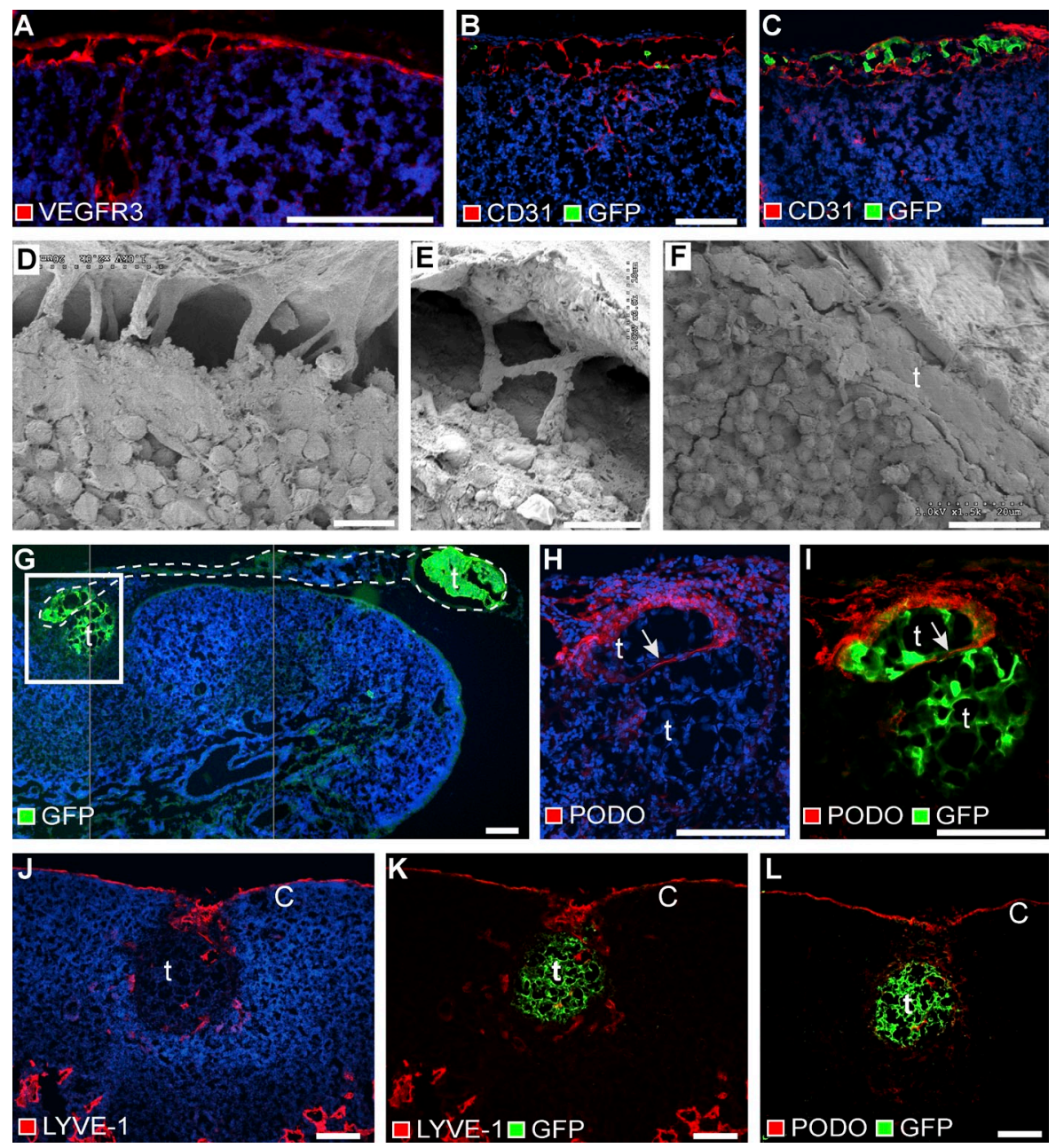

Figure 9. Steps of lymph node metastasis. (A-C) SCS of the sentinel lymph node stained with Abs against VEGFR-3 or CD31 as indicated. (A) Dilation of lymphatic sinuses before the entry of tumor cells. VEGFR-3 immunostaining visualizes LECs of the sinuses and the columns connecting the floor and the roof of the sinus. (B) Single tumor cells (GFP, green) present in the lumen of the SCS or attached to the lymphatic endothelium. (C) Early stage of metastatic growth in the SCS along the lymphatic endothelium. (D-F) Scanning electron microscopy micrographs depicting architecture of the SCS at high resolution. (D) Lymphatic endothelia at the roof and the floor of the SCS are connected by numerous column-like structures. (E) Horizontal bridges between the columns in the subcapsular space. (F) Metastatic lesion confined to the SCS. (G) Metastasis in the afferent lymphatic vessel (dashed line) at the junction with the lymph node (boxed area). Image shown is a composite of three images stitched together. (H and I) High magnification of the boxed area in $\mathrm{G}$, showing metastasis in the SCS at the junction of the lymphatic vessel and the $L N$ and in the adjacent LN cortex. Lymphatic endothelium at the border to the lymph node cortex, i.e., the floor of the SCS, is immunostained for podoplanin (arrows). (J-L) Metastasis in the LN parenchyma. Lymphatic vessels are stained with the Abs to LYE-1 ( and K), podoplanin (L), MDAcl.6 (A), or MDA cl.13 (B-L). t, tumor; c, capsule. Bars: (D and E) $10 \mu m$; (F) $20 \mu m$; (A-C and $\mathrm{H}-\mathrm{L}$ ) $100 \mu \mathrm{m} ;$ (G) $200 \mu \mathrm{m}$.

in-transit metastases increased from 46 to $78 \%$ (control 6/13 vs. MC148 7/9 positive LN, respectively), and in SK-MEL-25 from 0 to $33 \%$ (control 0/14 vs. MC148 4/12 positive LN, respectively). The incidence of lymph node metastases was significantly decreased in all tumor models when CCR8 was inhibited (Fig. 5 G).

Collectively, these observations demonstrate that the junction of the afferent lymphatic vessel and the lymph node sinus represents a barrier for tumor cell entry into the lymph node. Furthermore, the data indicate that blocking CCR8 on tumor cells prevents tumor cell extravasation from the collecting lymphatics into the lymph node, but it does not inhibit tumor cell entry into the lymphatics at the primary tumor site.

\section{Sequential steps of lymph node metastasis}

We next sought to characterize the sequence of events leading to lymph node metastasis by immunostaining, scanning electron microscopy, and multiphoton intravital imaging. We have observed that dilation of the SCS preceded the arrival of MDAcl.13 tumor cells into the sentinel lymph nodes (Fig. 9, A-C; and Fig. 6 J). The SCS was lined by a continuous layer of LECs which stained positive for CD31, VEGFR-3, podoplanin, and LYVE-1 (Fig. 9, A-C and J-L). Furthermore, 
the SCS was traversed by the columns connecting the roof and the floor of the sinus, which were continuous with the lymphatic endothelium and also stained positive for CD31, VEGFR-3, podoplanin, and LYVE-1 (Fig. 9, A and B; and not depicted). High resolution analysis by scanning electron microscopy showed numerous columns within the sinus, spaced on average $11.9 \mu \mathrm{m}$ apart from each other (range: 6.2-20.8 $\mu \mathrm{m}$; mean column diameter: $2.0 \mu \mathrm{m} \pm 0.61$; Fig. $9 \mathrm{D}$ ). The mean height of the dilated sinus was $8.6 \mu \mathrm{m}$ (range: 4.5-13.0 $\mu \mathrm{m})$. Some columns were transversally interconnected (Fig. 9 E), dividing the space within the sinus further into smaller compartments with a mean diameter of $5.25 \mu \mathrm{m}$ (range: $3.6-7.8 \mu \mathrm{m}$ ). These studies revealed a complex microanatomy of the SCS and suggested that the small dimensions of the SCS and the columns bridging the SCS may pose a barrier for the free movement of cell clusters laterally into the sinus.

Multiphoton imaging studies in live mice showed that the tumor lesion at the junction of the lymphatic vessel and the SCS exhibited very little movement; only occasional single cells were seen extending and retracting protrusions (Fig. 10, $\mathrm{A}$ and B; and Video 1). In the SCS, which was visualized by Evans blue lymphatic tracer and imaged at $35 \mu \mathrm{m}$ below the lymph node capsule, small tumor clusters consisting of as few as five cells were stationary and did not move through the sinus with the flow of lymph within the observation period of several hours. In contrast, many leukocytes were actively crawling through the sinus with mean velocity of $3.4 \mu \mathrm{m} / \mathrm{min}$ (Fig. 10 C, Video 2, and not depicted). Lymph flow into the sinus was not hindered by the tumor metastasis because the SCS readily filled with the Evans blue tracer, and it was evident that some leukocytes were passively drifting through the sinus with the flow of lymph at much higher velocities. Several single tumor cells present in the SCS were devoid of any movement, suggesting that they were adherent to the lymphatic endothelium. In addition, individual tumor cells were seen slowly moving through the SCS (mean velocity $0.5 \mu \mathrm{m} / \mathrm{min}$ ) independently of lymph flow (Fig. 10 D,Video 3, and not depicted). In agreement with these real-time in vivo observations, immunostaining of tissue sections showed single cells and small clusters of tumor cells attached to the lymphatic endothelium of the SCS (Fig. 9, B-D).

Intravital imaging of metastases further upstream in the collecting lymphatic vessels showed small and large tumor cell clusters that were not moving with the flow of lymph during the time examined but were attached to the luminal surface of the lymphatic endothelium (Fig. 10, E and F; and Video 4). Within the tumor cell clusters, some cells exhibited amoeboid movement and were seen migrating into a different position (Fig. $10 \mathrm{~F}$ and Video 4). Tumor cell clusters were only partially obstructing the lymphatic vessel lumen, suggesting that the tumor cell arrest at the lymphatic vessel wall occurred by an active mechanism and not because the tumor cell emboli occluded the vessel lumen.

Once tumor cells reached the lymph node, in some cases they seemed to have crossed the floor of the SCS right at the
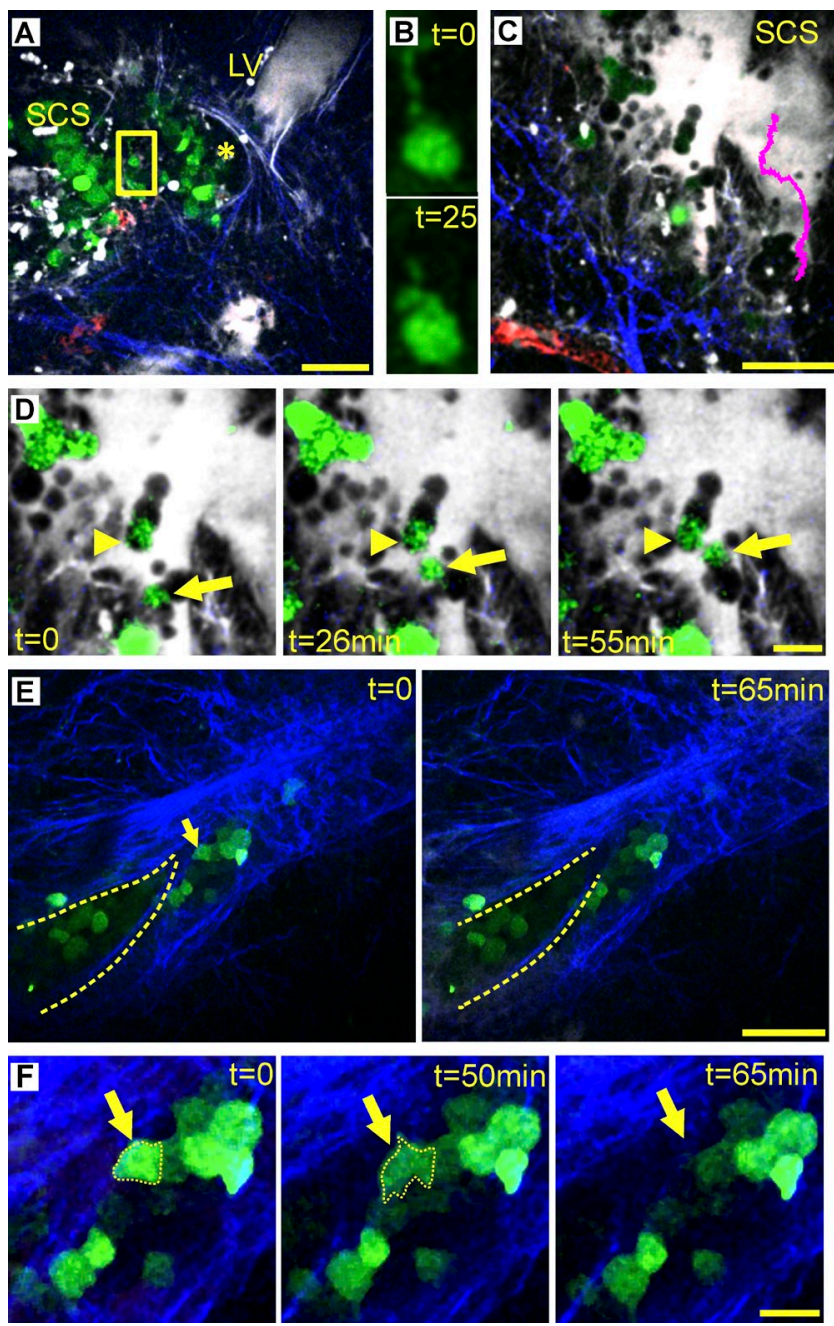

Figure 10. Intravital multiphoton imaging of metastases. (A-F) Still images from the time-lapse videos (Videos 1-4) obtained by in vivo multiphoton microscopy of metastases from MDAcl.13 tumors. (A-D) Metastasis at the junction of the afferent lymphatic vessel and the lymph node. (A) Maximum intensity projection image showing an afferent lymphatic vessel leading into the SCS (junction is indicated by *). Collagen fibers of the lymph node capsule and the lymphatic vessel wall are visualized by SHG (blue). SCS contains a large cluster of tumor cells (GFP, green). Evan's Blue tracer (white) labels the lymphatic vessel and the SCS. Some LN cells have taken up the Evan's blue dye and appear white. Blood vessels are labeled by i.v. injection of $2 \mathrm{MDa}$ rhodamine dextran (red). (B) Higher magnification of the boxed area in A ( $25 \mu \mathrm{m}$ wide) showing a tumor cell with an extended and retracted protrusion at different time points as indicated in minutes. (C and D) Tumor cells (GFP, green) in the SCS (white) in the single plane $35 \mu \mathrm{m}$ beneath the LN capsule. Leukocytes in the SCS appear black on the white background. (C) The pink line delineates movement of one leukocyte tracked over 61 min (distance traveled: $210 \mu \mathrm{m}$ ). (D) Higher magnification view showing one tumor cell which changed position (arrows) and another tumor cell in the proximity which remained stationary (arrowheads). (E) Tumor cell clusters in the collecting, afferent lymphatic vessel remain in the same position within the 65-min observation period. Lymphatic valve (dashed lines) is shown closed and partially open at indicated time points. Arrow points to a migrating cell. (F) Higher magnification of an area in E. A single cell is shown (arrows, dotted lines) which migrates into a different plane within the $20 \mathrm{~min}$ from the onset of cell shape change. See also Videos 1-4. LV, lymphatic vessel. Bars: (A, C, and E) $100 \mu \mathrm{m}$; (D and F) $30 \mu \mathrm{m}$. 
junction of the afferent lymphatic vessel and the lymph node (Fig.9, G-I). In most cases, however, metastases were first seen in the SCS (Fig. 9, B, C, and F) and then later in the lymph node cortex (Fig. 9, J-L). Metastases continued to grow within the subcapsular space and eventually completely occluded the SCS (Fig. 9 F). Remarkably, the integrity of the lymphatic endothelial layer was not disrupted even when very large lesions were present within the sinus. Collectively, these data indicate that the egress of tumor cells from the afferent lymphatic vessel into the lymph node consists of at least two distinct steps: (1) tumor cells entry into the SCS and (2) subsequent transmigration across the floor of the SCS into the lymph node cortex. We conclude that the entry of tumor cells into the lymph node cortex requires active cell migration.

\section{DISCUSSION}

We have demonstrated here that the entry of tumor cells from the afferent lymphatics into the lymph nodes requires activation of the CCR 8 receptor on tumor cells. Inhibition of CCR 8 led to the arrest of tumor cells in the collecting lymphatic vessels and prevented lymph node metastases. CCL1, the ligand for CCR8, was expressed by lymph node lymphatic sinus, but not by lymphatic capillaries, indicating that the signals from lymph node SCS LECs control tumor cell entry into the node. These data identify lymph node LECs as a critical checkpoint for entry of metastases into the lymph nodes.

Although the recent data indicate that the entry of cells from peripheral tissues into the lymphatics is regulated by chemokines (Debes et al., 2005; Shields et al., 2007b), the exit of cells from the collecting lymphatics into the lymph node has been considered a passive process (Nathanson, 2003; Achen et al., 2005; Alitalo et al., 2005). Conventional wisdom implies that tumor cells which enter lymphatics will be delivered into the draining lymph nodes by the flow of lymph. Our data challenge the current paradigm and indicate that the exit from the afferent lymphatics into the lymph node is a distinct, controlled step, thus adding the rate of tumor cell egress from the afferent lymphatics as another rate limiting step for metastasis.

Our experiments revealed that the entry of tumor cells into the lymph node consists of at least two sequential phases: (1) tumor cell entry into the sinus and (2) subsequent migration across the floor of the sinus into the LN cortex. Both steps require active cell migration in the tumor models examined. Blocking CCR8 prevented tumor cells from entering laterally into the sinus and from transmigrating across the LECs into the LN cortex, which led to the arrest of tumor cells at the junction of the afferent lymphatic vessel and the LN. Notably, based on the ultrastructural appearance of rat carcinoma cells in the LN sinuses, it has been suggested three decades ago that rat mammary carcinoma cells first settle and proliferate in the SCS and then invade across the lining of the sinus by active movement (Carr et al., 1985). Furthermore, consistent with our findings, one study reported that when delivered directly into the lymphatic system, human osteosarcoma and murine melanoma cells arrest at the junction of the afferent lymphatic vessel and the LN (Hayashi et al., 2007).

In the majority of the cases, SCS was the first site of lymph node metastasis in the tumor models we examined, which is consistent with the clinical observations (Carr, 1983; Dewar et al., 2004). We were puzzled by the finding that blocking of CCR8 inhibited tumor cell entry into the sinus, which is typically depicted as a hollow space to which lymph and leukocytes have free access. On the contrary, we noted that in the naive mice SCS did not have an open lumen, as determined by light microscopy and scanning electron microscopy. Similarly, lymphatic capillaries are generally observed in a collapsed state and are presumed to open only transiently (Pepper and Skobe, 2003). It is plausible that the closed SCS may preclude passive flow of tumor clusters, and even single cells, into the sinus. The dilation of the sinus may be a prerequisite for allowing the entry of tumor cells into the SCS because in tumor-bearing mice, pronounced dilation of the sinus always preceded the arrival of tumor cells, independent of CCR8CCL1 interaction. Tumor clusters may not even be able to enter into the dilated sinus as floating emboli based on the size restriction. Dilated sinuses in mice measured, on average, $8.6 \mu \mathrm{m}$ in diameter, whereas the diameter of a circulating tumor cell is at least $15 \mu \mathrm{m}$ on average (Vona et al., 2000) and the size of tumor microemboli correspondingly larger. Scanning electron microscopy studies revealed that the SCS was further divided vertically and horizontally into smaller compartments, resulting in passages $5-15 \mu \mathrm{m}$ wide, consistent with the previous studies which showed that the SCS in rat LNs is supported by the intraluminal cells which create a meshwork within the sinuses (Ohtani and Ohtani, 2008; Jia et al., 2012). It remains to be determined whether human lymph nodes exhibit similar features. These studies revealed a complex microanatomy of the SCS and suggested that the narrow passages within the sinus impede passive flow of tumor clusters laterally into the sinus.

We showed by intravital imaging that some tumor cells crawled slowly through the sinus with the mean velocity of $0.5 \mu \mathrm{m} / \mathrm{min}$. For comparison, single tumor cells in primary tumors have been reported to move at speeds ranging from 0.1 to $4 \mu \mathrm{m} / \mathrm{min}$ (Condeelis and Segall, 2003; Roussos et al., 2011). The rate of tumor cell movement in the SCS was much slower than the reported flow velocities of lymph, which range from $\sim 180 \mu \mathrm{m} / \mathrm{min}$ in lymphatic capillaries to up to 1,300 $\mu \mathrm{m} / \mathrm{min}$ in the collecting vessels (Swartz, 2001; Dadiani et al., 2006; Tal et al., 2011), further precluding the possibility that the observed cell movement was a result of passive drifting with the flow. Within the SCS, single cells and tumor cell clusters were seen attached to the luminal side of LECs, suggesting active adhesion. Similarly, in the afferent collecting lymphatics, many tumor clusters not fully obstructing the lumen were adherent to the LEC lining, indicating that the occlusion of the vessel with the tumor is not a result of mechanical entrapment of large tumor clusters but a consequence of active adhesion to LECs and subsequent growth. Collectively, these results suggest a scenario whereby tumor cells advance 
from the lymphatic vessel into the SCS as a combination of cell migration along the sinus and the concomitant growth.

CCL1 produced by the SCS LECs may promote tumor cell entry into the LN by increasing tumor cell motility. This is supported by our data, which showed that activation of CCR 8 on tumor cells by the soluble CCL1 induced cytoskeletal changes and chemotaxis in vitro. Furthermore, in support of the concept that CCL1 facilitates luminal to basal transmigration across LECs, immunostaining revealed that CCL1 can be displayed on the apical surface of the LECs, and solitary tumor cells which traversed the floor of the SCS were seen immediately below the endothelium. Chemokines presented by the endothelium are critical for integrin-dependent adhesion and transendothelial migration and are particularly efficient in promoting cell motility (Alon and Ley, 2008; Schumann et al., 2010; Alon and Shulman, 2011).

The junction of the lymph node with the afferent lymphatic may also be a checkpoint for entry of other cells that traffic from the periphery to lymph nodes. Notably, it was shown recently that afferent lymph-derived DCs are retained in the SCS proximal to the junction with the afferent lymphatic vessel (Braun et al., 2011). From here, DCs transmigrated across the floor of the SCS into the T cell zones (Braun et al., 2011; Förster et al., 2012). DCs and memory T cells express CCR8 (Gombert et al., 2005; Soler et al., 2006) and blocking CCR 8 was shown to decrease the number of DCs in the draining lymph nodes (Qu et al., 2004), suggesting that CCR 8 may also control entry of leukocytes into the LN. Hence, tumor cells might exploit the mechanisms of cell traffic which operate in the physiological setting. In cancer, expression of chemokine receptors CCR7 and CXCR 4 on tumor cells has been associated with lymph node metastasis (Müller et al., 2001; Wiley et al., 2001; Mashino et al., 2002; Cabioglu et al., 2005; Ishigami et al., 2007). The role of these and other chemokines/receptors in regulating LN entry remains to be elucidated.

Given the complexity of the lymph node architecture and the tight control of leukocyte traffic in the lymph nodes, it is surprising that tumor cells arriving from the afferent lymph are thought to have unrestricted access to the lymph node parenchyma. Notably, lymph-borne molecules do not have free access into the lymph node (von Andrian and Mempel, 2003). Studies using fluorescently labeled tracers have demonstrated that soluble antigens do not freely diffuse into the lymph node parenchyma but are retained within the subcapsular or medullary sinuses (Fossum, 1980; Szakal et al., 1983; Gretz et al., 2000; von Andrian and Mempel, 2003). Although small molecules with a molecular mass below $70 \mathrm{kD}$ (or $<5 \mathrm{~nm}$ ) can gain access to the LN cortex through fibroblastic reticular cell (RFC) conduit, molecules $>5.5 \mathrm{~nm}$ remain confined to the sinus (Gretz et al., 2000; von Andrian and Mempel, 2003; Pape et al., 2007; Pfeiffer et al., 2008; Roozendaal et al., 2009). Hence, small molecules, such as chemokines, can travel through the LN conduit system, whereas antigens and immune complexes remain in the SCS (Fossum, 1980; Szakal et al., 1983; Gretz et al., 2000; Pape et al., 2007) and require cellular transport (Phan et al., 2007). However, select macromolecules, such as antibodies, can gain access to the LN parenchyma (von Andrian and Mempel, 2003), indicating that the selectivity is not based solely on size exclusion. In addition to preventing diffusion of soluble molecules into the lymphocyte compartment, the SCS is an important site for preventing systemic spread of microorganisms and viruses (Junt et al., 2007). These results are consistent with our conclusion that lymphatic endothelium of the sinus represents a barrier for entry of tumor cells into the lymph node.

The LN cortex is protected from the direct contact with the afferent lymph by SCS-lining LECs (Sainte-Marie et al., 1982; Düllmann et al., 2002; Junt et al., 2007; Phan et al., 2007; Pfeiffer et al., 2008), which are also referred to as the floor of the SCS (Gretz et al., 2000; Junt et al., 2007). LECs lining the sinus possess tight junctions and a basal membrane, indicating a diffusion barrier (Pfeiffer et al., 2008). One study showed that high-molecular mass dextran was taken up by lymphatic capillaries but did not cross the SCS LEC layer (Pfeiffer et al., 2008), suggesting that SCS LECs have different barrier properties than peripheral lymphatics. SCS LECs also differ from lymphatic capillaries by the surface markers and junctional molecules expression (Martens et al., 2006; Pfeiffer et al., 2008); however, the true functional differences between the peripheral lymphatics and SCS LECs are yet to be determined. Collectively, these data point to an emerging concept - that LECs of the SCS play a critical role in regulating the access of soluble molecules as well as cells into the LN.

We show that the CCL1 is constitutively expressed by SCS LECs, but not by lymphatic capillaries in the skin, and thus conclude that CCR 8 does not play a role in intravasation of cancer cells into the peripheral lymphatics. This is in agreement with the previous studies which also did not find CCL1 in peripheral lymphatics and, therefore, concluded that CCL1 does not play a role in the exit of $\mathrm{CCR}^{+} \mathrm{T}$ cells and DCs from the tissues (Qu et al., 2004; Schaerli et al., 2004). Thus far, constitutive CCL1 expression has been detected in several types of immune cells, in blood endothelium of the skin, and in melanocytes (Miller et al., 1989; Schaerli et al., 2004; Gombert et al., 2005). Expression of CCL1 by blood endothelium raises a possibility that CCL1-CCR 8 could also be important for tumor cell homing to distant organs and for the formation of secondary skin metastases, which are frequent in melanoma. The importance of the CCL1-CCR 8 axis in distant metastasis, however, remains to be investigated. Upon inflammatory stimulation, CCL1 expression was dramatically increased in lymphatic capillaries, in agreement with the previous work which found a marked induction of CCL1 expression in blood endothelial cells (BECs), DCs, and mast cells in inflammation (Gombert et al., 2005). Notably, we show that CCL1 was a key molecule mediating chemotaxis of tumor cells to inflamed lymphatic endothelium, suggesting that in the setting of inflammation, CCL1 may also facilitate entry of $\mathrm{CCR}^{+}$tumor cells into the peripheral lymphatics. In contrast, CCL1 was only partially responsible for tumor cell 
migration to unstimulated LECs, pointing to the role of additional chemokines in the steady state. These data imply an important link between inflammation and lymphatic metastasis.

There is a discrepancy in the literature regarding the ability of mouse CCL1 to activate human CCR8. One study found that mCCL1 stimulates calcium mobilization in human THP-1 cells (Luo et al., 1994). In agreement, vMIP-I, a viral homologue of CCL1, is an agonist for human and mouse CCR8 (Lüttichau et al., 2001). However, another study reported that mCCL1 did not induce [ $\left.\mathrm{Ca}^{2+}\right]$-flux in 293-EBNA cells expressing hCCR8 (Goya et al., 1998). We conclude that mCCL1 is an agonist for human CCR8 based on several lines of evidence. mCCL1 induced $\left[\mathrm{Ca}^{2+}\right]$-flux in three human cell lines: in HEK293 cells overexpressing CCR8 and in SKMEL-25 and MDA-MB-435 cells, which endogenously express CCR8. $\left[\mathrm{Ca}^{2+}\right]$-flux induced by mCCL1 was blocked with a specific CCR8 antagonist, MC148, and mCCL1 triggered cytoskeletal rearrangement in human cells. A recent study found that mouse CCL8 is a second agonist for CCR8; however, a human ortholog has not yet been found (Islam et al., 2011). We detected CCL8 protein only in mouse skin keratinocytes, consistent with the previous findings (Islam et al., 2011), but not in lymphatic vessels, tumors, or lymph nodes. Therefore, CCL8 was not expressed at the right time and place to play a role in regulating the entry of tumor cells into the lymph nodes.

Human CCL1 is a selective ligand for CCR 8 (Roos et al., 1997; Tiffany et al., 1997; Goya et al., 1998). This selectivity is unusual, as most chemokine receptors bind to more than one chemokine and vice versa (Houshmand and Zlotnik, 2003). The very restricted pattern of CCR 8 expression in tissues is also quite unusual and makes CCR 8 an attractive therapeutic target (Schaerli et al., 2004). Our data showing expression of CCR 8 in malignant melanoma and its role in lymph node metastasis suggest that CCR 8 could be explored as a potential therapeutic target in melanoma. To date, CCR8 expression has been reported primarily on a subset of $\mathrm{T}$ cells with role in allergic inflammation, further supporting the concept that blocking CCR 8 for therapeutic purposes could have relatively little off target effects.

In conclusion, we demonstrate here a novel function for CCL1/CCR8 and lymph node LECs in controlling tumor cell entry into the lymph node. Our work adds to the growing body of evidence indicating that lymphatic vessels are not only a drainage and transportation system but that LECs play an active role in several important biological events, including metastasis (Skobe et al., 2001b; Debes et al., 2005; Jamieson et al., 2005; Podgrabinska et al., 2009; Cohen et al., 2010).

\section{MATERIALS AND METHODS}

Cell culture. Human LECs and BECs were isolated and cultured in endothelial basal medium (EBM; Lonza) supplemented with 20\% FBS (Invitrogen) as previously described (Podgrabinska et al., 2002). The breast epithelial cells MCF10F were cultured in DMEM/Ham's F12 (Shafie and Liotta, 1980; Soule et al., 1990) and 184B5 cells in MEBM/MEGM (Walen and Stampfer, 1989; Lonza/Clonetics Corporation). Primary human melanocytes isolated from human foreskins (gift from S.A. Aaronson, Mount Sinai School of
Medicine, New York, NY) were cultured in Medium 254 (Cascade Biologicals). The human breast cancer cell lines MDA-MB-231, MDA-MB-435, and MCF-7 were cultured in DMEM with 10\% FBS. Melanoma cell lines SK-MEL-25, SK-MEL-28, and MEL-501, and Jurkat cells, were cultured in RPMI-1640 containing 5\% FBS (Zakut et al., 1993; Podgrabinska et al., 2009). Conditioned medium (CM) was generated from just confluent LECs or BECs in passage 4-6, cultured for $48 \mathrm{~h}$ in EBM/1\% FBS. In some experiments, LECs were treated with $50-100 \mathrm{ng} / \mathrm{ml} \mathrm{TNF}, 500 \mathrm{ng} / \mathrm{ml} \mathrm{LPS}$, or $50 \mathrm{ng}$ IL-1 $\beta$ for $48 \mathrm{~h}$ or as indicated in the figure legends. CM from tumor cells and Jurkat cells were generated serum free in their respective media.

Reagents and antibodies. Recombinant human CCL1, mouse CCL1, and viral MCV-type II chemokine-like protein MC148 were purchased from R\&D Systems. We also used E. coli LPS (serotype 0127:B8; Sigma-Aldrich), recombinant human and mouse TNF (PeproTech), IL-1 $\beta$ (R\&D Systems), FITC (Sigma-Aldrich), pertussis toxin (List Biological), cholera toxin (SigmaAldrich), Alexa Flour 594 phalloidin (Life Technologies), and Hoechst bisbenzimide (Sigma-Aldrich). Anti-human antibodies: goat anti-CCR8 (Alexis Biochemical), rabbit anti-CCR8 (Abcam), goat anti-CD31 (Clone C20; Santa Cruz Biotechnology, Inc.), mouse anti-podoplanin (AngioBio; Fitzgerald), goat anti-CCL1 (Clone C19; Santa Cruz Biotechnology, Inc.), mouse anti-CCL1 (Clone 35305; R\&D Systems), isotype control IgG1 (R\&D Systems). Anti-mouse antibodies: rabbit anti-LYVE-1 (Abcam), rat anti-CD31 (Clone RAM34; BD), goat anti-VEGFR-3 (R\&D Systems), hamster antipodoplanin (AngioBio), goat anti-CCL1 (R\&D Systems), goat anti-CCL8 (R\&D Systems). Rabbit anti-His antibody Clone H15 was from Santa Cruz Biotechnology, Inc., and chicken anti-GFP antibody was from Abcam. Secondary antibodies were labeled with Alexa Fluor 488, 555, 594, or 647 (Life Technologies) or with biotin (Vector Laboratories).

RT-PCR and qPCR. RT-PCR was performed as described (Podgrabinska et al., 2002). The expression levels of hCCL1 mRNA were quantified by SYBR green-based real-time PCR using the Opticon2 detection system (Bio-Rad Laboratories) as described previously (Podgrabinska et al., 2009) on the RNA isolated from LECs treated with $50 \mathrm{ng} / \mathrm{ml} \mathrm{TNF}$, $500 \mathrm{ng} / \mathrm{ml} \mathrm{LPS}$, or $50 \mathrm{ng} / \mathrm{ml} \mathrm{IL}-1 \beta$ for 3,6 , and $18 \mathrm{~h}$. Jurkat cells were treated with $50 \mathrm{ng} / \mathrm{ml}$ PMA for $48 \mathrm{~h}$. Primers used for RT-PCR and qPCR were: hCCR 8 Fp70, 5'-CCCTGTGATGCGGAACTTAT-3'; hCCR8 Rp711, 5'-GATGGCCTTGGTCTTGTTGT-3'; hCCR8 Fp410, 5' -ATGCCGTGTATGCCCTAAAG-3'; hCCR8 Rp707, 5'-GCCTTGGTCTTGTTGTGGTT-3'; hCCL1 Fp, 5'-GGAAGATGTGGACAGCAAGAGC-3'; and hCCL1 Rp, 5'-TGTAGGGCTGGTAGTTTCGG-3'. MC148 primers are shown below.

Cloning and cell transfections. MC148 was PCR amplified from a pTejMC148 vector (gift from H.R. Luttichau, Panum Institute, University of Copenhagen, Copenhagen, Denmark) using the Expand High Fidelity plus PCR system (Roche), with the forward primer containing a Nhe I restriction site (bold) and the reverse primer containing an Apa I restriction site (bold), following a His tag sequence (underlined). MC148 Fp, 5'-AAAAGCTAGCACCATGAGGGGCGGAGACGTCTTC-3'; and MC148 Rp, 5'-AAAAGGGCCCTCAATGATGATGATGATGATGCAGAGACTCGCACCCGGACCATAT-3'. The PCR-amplified product was cloned into a pcDNA 3.1-Hygro (+) vector (Life Technologies). Tumor cells were transfected with the expression construct pcDNA3.1/MC148-His or with an empty vector using the Lipofectamine 2000 reagent (Life Technologies), selected, and maintained in media with $100 \mu \mathrm{g} / \mathrm{ml}$ Hygromycin. MDAcl.13 and MDAcl.6 cells were selected and used as a whole population. SK-MEL-25 cells were subcloned and one control (C2) and one MC148 clone (M2) were used in the experiments. HEK 293 cells were transfected with the hCCR 8 plasmid (Tiffany et al., 1997). For silencing CCR 8 gene expression, shRNA oligos were cloned into the pLKO.1-puro lentiviral vector (Addgene) according to the standard protocol. For generation of the lentiviral particles, these constructs were transfected into $293 \mathrm{~T}$ cells along with the packaging plasmids psPAX2 (Addgene) and pMD2.G (Addgene). Culture supernatants containing 
viral particles were collected $48 \mathrm{~h}$ after transfection. Stable shRNA-expressing cells were generated by infection with viral particles in presence of $8 \mu \mathrm{g} / \mathrm{ml}$ polybrene and selection with $2 \mu \mathrm{g} / \mathrm{ml}$ puromycin. The shRNA sequences used are as follows: shCCR8(1), 5'-GGATTATACACTTGACCTCAGTG-3'; shCCR8(2), 5'-CCTCCAGCGTAGACTACATTT-3'; and shScrambled, 5'-CCTAAGGTTAAGTCGCCCTCGC-3' . MDA-MB-435/GFP cells used in shRNA knockdown experiments were generated by infecting cells with the $\mathrm{pBabe}$-derived retroviral vector containing CMV promoter-driven EGFP (gift from S.A. Aaronson) and selecting for the population resistant to hygromycin.

Western blot and ELISA. Western blot analyses were performed as previously described (Skobe et al., 2001b). For CCL1 detection, $5 \mathrm{ml} \mathrm{CM}$ (from $\sim 2 \times 10^{6}$ ECs) was incubated with heparin-Sepharose beads (Pharmacia) and eluted by boiling with $40 \mu \mathrm{L}$ Laemmli sample buffer. Whole sample was loaded onto the gel. For MC148 detection, $5 \mathrm{ml} \mathrm{CM}$ (from $\sim 7 \times 10^{6}$ tumor cells) was concentrated 10-fold using Amicon Ultra Centrifugal Filter Units (Ultracel-3K; Millipore) and $10 \mu \mathrm{l}$ was loaded on the gel. CCR 8 Western blot analyses were performed on lysates of cultured cells and on tumor lysates as previously described (Skobe et al., 2001b). Antibodies used were rabbit anti-human CCR8, goat anti-human CCL1, and rabbit anti-His for detection of His-tagged MC148. hCCL1 in the culture supernatants was measured with an ELISA kit (RayBio).

Chemotaxis assays. Tumor cell migration was assessed using 24-well plate Transwell system with $8.0-\mu \mathrm{m}$ pore inserts (BD). EBM with $1 \%$ FBS or LEC-CM media $(700 \mu \mathrm{l})$ was added into the well, and tumor cells into the insert $\left(2 \times 10^{5}\right.$ in $\left.200 \mu \mathrm{l}\right)$. In the experiments with SK-MEL-25 cells, inserts were coated with $50 \mu \mathrm{g} / \mathrm{ml}$ collagen and $1 \mu \mathrm{g} / \mathrm{ml}$ fibronectin. For blocking studies, tumor cells were pretreated with $100 \mathrm{ng} / \mathrm{ml} \mathrm{PTx}$ or CTx for $16 \mathrm{~h}$. $2 \mu \mathrm{g} / \mathrm{ml}$ anti-CCL1 Ab or $2 \mu \mathrm{g} / \mathrm{ml}$ isotype control $\operatorname{IgG}_{1}$ was added to LEC$\mathrm{CM}$ for duration of the experiment. For CCL1 immunodepletion, LEC-CM was preincubated with either $2 \mu \mathrm{g} / \mathrm{ml}$ mouse anti-human CCL1 Ab or isotype control $\operatorname{IgG}_{1}$ for $2 \mathrm{~h}$, followed by incubation with protein $\mathrm{G}$ Sepharose beads (Santa Cruz Biotechnology, Inc.). Sepharose beads were removed by centrifugation and CCL1-depleted CM used in the assays. For CCR 8 blocking, $100 \mathrm{ng} / \mathrm{ml}$ MC148 antagonist (Lüttichau et al., 2001) was preincubated with tumor cells for $30 \mathrm{~min}$ before the assay. In the experiments where LECCM was generated in presence of $50 \mathrm{ng} / \mathrm{ml} \mathrm{TNF}$ or $500 \mathrm{ng} / \mathrm{ml}$ LPS was used (48-h conditioning), EBM supplemented with TNF or LPS was used as a control. Tumor cells were allowed to migrate for $6 \mathrm{~h}$, fixed, stained with Hoechst, and examined as previously described (Skobe et al., 2001a) using a microscope (E-600; Nikon). Images from four different fields in each membrane were captured with a fluorescence microscope (10×; Eclipse E600; Nikon) equipped with a camera (DS-Qi1MC; Nikon) and the total area of migrated cells quantified using IPLab software. All experiments were performed in triplicate. Statistical significance was determined using a two-tailed Student's $t$ test.

Actin polymerization assay. $3 \times 10^{4}$ tumor cells were incubated overnight in 8 -well chamber slides (BD) with $1 \%$ FBS and then treated with $50 \mathrm{ng} / \mathrm{ml} \mathrm{rCCL} 1$ (human or mouse) for the indicated times. Cells were fixed (4\% PFA), permeabilized ( $0.1 \%$ Triton X-100) and stained with rhodaminelabeled phalloidin. Images were captured by a Nikon microscope (described above). For the blocking experiments, cells were incubated with $50 \mathrm{ng} / \mathrm{ml}$ MC148 and $50 \mathrm{ng} / \mathrm{ml}$ PTx for $1 \mathrm{~h}$ before the addition of rCCL1.

Flow cytometry and calcium fluorimetry. For CCR 8 expression, melanocytes and tumor cell lines were detached, stained with goat anti-human CCR 8 (1:400) in PBS/10\% FBS for 45 min, washed, incubated with FITCconjugated corresponding secondary $\mathrm{Ab}$, washed, and analyzed by flow cytometry (BD). $\mathrm{Ca}^{2+}$-flux assay was essentially performed as previously described (Lüttichau et al., 2000). In brief, cells were mechanically detached from the culture dish, washed, and loaded with Fluo-4 AM dye (Molecular Probes) in serum-free DMEM with 4\% BSA. Cells were incubated for $60 \mathrm{~min}$, washed in Krebs ringer buffer several times, and the fluorescence kinetics was measured on a FACSCalibur (BD). Ionomycin served as a positive control. For blocking studies, $25 \mathrm{nM}$ MC148 was added to the cell suspension before the addition of rCCL1. Data were analyzed using FlowJo software. Data were plotted as time versus percentile Fluo-4 intensity, with moving average smoothing option.

Induction of inflammation in the mouse skin. Mice (athymic $\mathrm{Ncr} \mathrm{Nu}$ / $\mathrm{Nu}$; NCI Frederick) were injected intradermally with recombinant mouse TNF (50 ng per injection) into the back skin. Alternatively, $8 \mathrm{mg} / \mathrm{ml}$ FITC was dissolved in equal volumes of acetone and dibutyl phthalate (SigmaAldrich) and applied to back skin $(3 \times 25 \mu \mathrm{l})$. Skin from naive mice was used as a control. Mice were sacrificed $24 \mathrm{~h}$ later, tissues were collected, fixed in formalin, sectioned $(6 \mu \mathrm{m})$ using a microtome (model 820; AO American Optical Spencer), immunostained, and examined for CCL1 as described below.

Metastasis assay and evaluation. To examine the role of CCR 8 in tumor metastasis we used three human tumor cell lines: (1) SK-MEL-25 melanoma cells, (2) highly metastatic subclone of MDA-MB-435 cells which expresses VEGF-C (MDAcl.13), and (3) parental MDA-MB-435 cells (Skobe et al., 2001b; Roberts et al., 2006; Das et al., 2010). In the experiments with MC148 antagonists, we used a subclone of MDA-MB-435 cells tagged with GFP (MDAcl.6; Skobe et al., 2001b; Roberts et al., 2006; Das et al., 2010). In the experiments with shRNA knockdown, we used parental MDA-MB-435 cells tagged with GFP as a whole population. MDA-MB-435 (parental, cl.6 or cl.13) and SK-MEL-25 cells were injected into immunodeficient mice (Athymic $\mathrm{Ncr} \mathrm{Nu} / \mathrm{Nu}$; NCI Frederick), into the second mammary fat pads $\left(2 \times 10^{6}\right.$ cells), and intradermally $\left(4 \times 10^{5}\right.$ cells), respectively. Metastases were evaluated at 13 and at $5 \mathrm{wk}$, respectively (when tumors reached $10 \mathrm{~mm}$ in diameter); tumors and lymph nodes were collected and processed as previously described (Skobe et al., 2001b; Das et al., 2010). LNs were carefully dissected to preserve the lymphatic vessels in the surrounding tissue and analyzed in toto with a stereomicroscope (MZ16F; Leica) equipped for epifluorescence. Images were captured with DFC300Fx camera using LAS V3.6 software (Leica). Metastases were classified in two groups: (1) intranodal metastasis refers to the samples which contain metastases inside the lymph node (with or without additional metastases in the collecting lymphatic vessel); (2) in transit refers to the metastases in the collecting, afferent lymphatic vessels attached to the LN, but without metastases in the lymph node itself. Absence or presence of LN metastases was also confirmed by examination of $100 \mu \mathrm{m}$ LN sections for the presence of GFP signal in the LN (Skobe et al., 2001b; Das et al., 2010). Specific sublocalization of tumor cells in the lymphatic vessels or in the LNs was further examined by immunostaining of thin sections $(6 \mu \mathrm{m})$ with lymphatic-specific markers and an anti-GFP antibody. Overall incidence of LN metastases was calculated as the number of positive LN relative to the total number of lymph nodes examined. Ratio of in transit to intranodal metastasis was calculated relative to the number of samples positive for metastases in either localization, not to the total lymph nodes examined. 10 mice ( 40 lymph nodes) were analyzed in each experimental group. For statistical analysis, generalized estimating equations were used to account for the intraclass correlation in the data. All animal experiments were performed in accordance with the protocols approved by the MSSM's Institutional Animal Care and Use Committee.

Multiphoton microscopy of fixed tissues. Lymph nodes were imaged using a multiphoton microscope (Radiance 2100MP; Bio-Rad Laboratories) equipped with a Tsunami pulsed laser (Spectraphysics) and controlled by Lasersharp 2000 software (Bio-Rad Laboratories). Formalin-fixed lymph nodes were immobilized in a Petri dish with agar, immersed in PBS, and viewed with the $20 \times$ water-immersion objective (NA 0.8). To image EGFP and collagen (by second harmonic imaging, SHG) laser excitation source was tuned to $840 \mathrm{~nm}$. EGFP signal was collected by using a 515/30 nm filter. Stacks of $x-y$ sections were acquired at $5 \mu \mathrm{m}$ vertical spacing. $2 \mathrm{D}$ image processing and subsequent $3 \mathrm{D}$ reconstruction was performed with Volocity software (Improvision).

Immunofluorescent staining. Immunofluorescent staining procedures were performed as previously described (Roberts et al., 2006; Das et al., 2010), 
with the following modifications: formalin-fixed (1 h, 10\%) cryosections of lymph nodes were treated with $0.3 \%$ Triton X-100 (in PBS) for $30 \mathrm{~min}$, washed, and stained as described. GFP detection was done using formalin-fixed cryosections, with an anti-GFP Ab. For CCL1 detection, paraffinembedded tumor and lymph node tissue sections were used and Alexa Fluor 555- and 647-conjugated secondary antibodies. Tissue was examined using a fluorescence microscope (Eclipse E600) equipped with a camera (DS-Qi1MC; Nikon). NIS Elements software (Nikon) was used for capture and quantification of images (tumor vasculature; Roberts et al., 2006).

Human tissues and immunohistochemistry. Two malignant melanoma tissue arrays (ME801 and ME241) containing a total of 90 cases of malignant melanoma were purchased from Biomix US. Archived samples of paraffinembedded human melanoma tissues $(n=19)$, lymph nodes with melanoma metastases $(n=8)$, and normal skin were obtained from the files of the Department of Pathology at Columbia University. Paraffin-embedded specimens were analyzed as previously described (Das et al., 2010). For CCR8 detection, goat anti-human CCR 8 antibody and the Vectastain ABC kit were used. For CCL1 detection, mouse anti-human CCL1 antibody and CSA amplification method (Dako) were used. Use of human tissue samples was approved by the Institutional Review Board of Columbia University.

Scanning electron microscopy. Mice were anesthetized, perfused with PBS at the controlled rate of $5 \mathrm{ml} / \mathrm{min}$ through the left ventricle and subsequently with $2 \%$ glutaraldehyde $/ 2 \%$ paraformaldehyde. Upon sacrifice, lymph nodes were excised and postfixed in the above fixative for $24 \mathrm{~h}$ at $4^{\circ} \mathrm{C}$. Lymph nodes were then embedded in $4 \%$ agarose and sectioned at $250-\mu \mathrm{m}$ intervals using a vibratome (VT100; Leica). Sections were examined with a microscope (Eclipse Ti; Nikon) to identify regions of interest and selected sections were processed for scanning electron microscopy according to the standard protocol (Ohtani et al., 2003), with the following modifications: primary fixation in $3 \%$ glutaraldehyde $/ 0.2 \mathrm{M}$ cacodylate buffer, $\mathrm{pH} 7.4$, for $3 \mathrm{~h}$, secondary fixation in $1 \% \mathrm{OsO}_{4} / 0.2 \mathrm{M}$ cacodylate buffer for $1 \mathrm{~h}$ After washing tissues were dehydrated in the ethanol series, critical point dried with liquid $\mathrm{CO}_{2}$ and coated with gold. Specimens were examined with a field emission scanning electron microscope (S-4300; Hitachi) under an accelerating voltage of $10 \mathrm{KV}$.

Intravital multiphoton microscopy. MDAcl.13 or MDAcl.13/MC148 cells tagged with EGFP were injected into the fifth mammary fat pads of immunodeficient mice $\left(2 \times 10^{6}\right.$ cells). Imaging of metastases was performed between 7 and $20 \mathrm{wk}$ after the tumor cell injection. To visualize sentinel lymph nodes and the afferent lymphatics draining the tumor, mice were anesthetized with 5\% isoflurane and $10 \mu \mathrm{l}$ Evan's blue tracer (1\%; Tsopelas and Sutton, 2002) was injected at the tumor site. In some experiments, Evan's blue was injected laterally at the tail base to identify inguinal lymph node before imaging. Lymph node and tumor-draining lymphatic vessels were exposed for imaging by performing a skin flap surgery as previously described (Lindquist et al., 2004; Wyckoff et al., 2011), with some modifications. A medial incision through the abdominal skin was performed, skin was gently separated from the underlying fascia, and the node was exposed by the careful removal of the overlying adipose tissue to spare lymphatic and blood vessels. The mouse was placed on the microscope stage within a heated chamber kept at $37^{\circ} \mathrm{C}$. Proper stabilization of the tissue to be imaged is crucial to ensure drift-free imaging over several hours. To achieve this, skin surrounding the exposed LN was stretched across a $1 \times 0.5$-inch rigid plasticbacked piece of foam and attached using surgical staples. To avoid compression of the tissue, two small pieces of rubber were placed at either end of the foam, creating a bridge spanning the tissue to be imaged, and the bridge was then fixed in place using adhesive tape. All animals were used according to the protocols that have been reviewed and approved by Albert Einstein's Institutional Animal Care and Use Committee.

Intravital imaging was performed on a custom-built, inverted multiphoton microscope system as described previously (Entenberg et al., 2011). The microscope's four detectors allow simultaneous imaging of collagen fibers (blue, second harmonic generation), GFP (green), rhodamine dextran (red), and Evan's blue (far red). All fluorescence signals were cleanly separable with minimal overlap in the filter sets used (Entenberg et al., 2011). To visualize blood vasculature, $2 \mathrm{MDa}$ rhodamine dextran was administered into the tail vein $(200 \mu \mathrm{l})$. A high molecular weight of dextran precludes leakage out of the vasculature, and its slow clearance rate enables vessel labeling for the duration of the experiment. Evan's blue fluorescence was used for visualizing the lymphatic vessels and lymph nodes. Evan's blue has narrow emission spectrum at $680 \mathrm{~nm}$ and long Stokes shift, allowing efficient excitation with a single 880-nm wavelength for all fluorophores (Li et al., 2012). 4D images were acquired at 1 fps with 5- $\mu \mathrm{m}$ z-steps spanning 100 to $150 \mu \mathrm{m}$ and with $\sim 1$ min between time points. Images were analyzed in ImageJ (National Institutes of Health) with minimal processing to remove noise (1 px median filter) and increase brightness and contrast where needed.

Online supplemental material. Video 1 shows metastasis of MDAcl.13 cells in the lymph node SCS at the junction with the afferent lymphatic vessel. Video 2 shows cell migration within the SCS. Video 3 shows a single tumor cell moving in the SCS. Video 4 shows intravital imaging of an in transit metastasis in the large afferent lymphatic vessel. Online supplemental material is available at http://www.jem.org/cgi/content/full/jem.20111627/DC1.

We thank Drs. Phil Murphy and Bernhard Moser for the CCR8 plasmid, Dr. Hans Rudolf Luttichau for the MC148 plasmid, Dr. Stuart A. Aaronson for primary melanocytes and the retroviral vector, Dr. Rumana Huq for help with multiphoton microscopy of fixed tissues, Drs. Peter Baluk, Konstantin Zakashansky, Gwendalyn Randolph, and Roshni Mitra for helpful discussions, Stefano Malerba for statistical analysis, and Tamara Edwards and Wu Zheng for technical assistance. We thank Dr. William Janssen and Juan Jimenez for help with scanning electron microscopy studies.

This work was supported by the Department of Defense grant BC044819 and by the grant from Emerald Foundation (M. Skobe). Microscopy work was performed at the MSSM-Microscopy Shared Resource Facility, supported with funding from National Institutes of Health (NIH)-National Cancer Institute shared resources grant (5R24 CA095823-04), National Science Foundation Major Research Instrumentation grant (DBI-9724504), and NIH shared instrumentation grant (1 S10 RRO 9145-01). Multiphoton intravital imaging was performed at the Gruss Lipper Biophotonic Center at Albert Einstein College of Medicine, NY, supported by CA163131 (J. Condeelis).

The authors have no conflicting financial interests.

Submitted: 3 August 2011

Accepted: 26 June 2013

\section{REFERENCES}

Achen, M.G., B.K. McColl, and S.A. Stacker. 2005. Focus on lymphangiogenesis in tumor metastasis. Cancer Cell. 7:121-127. http://dx.doi .org/10.1016/j.ccr.2005.01.017

Alitalo, K., T. Tammela, and T.V. Petrova. 2005. Lymphangiogenesis in development and human disease. Nature. 438:946-953. http://dx.doi .org/10.1038/nature04480

Alon, R., and K. Ley. 2008. Cells on the run: shear-regulated integrin activation in leukocyte rolling and arrest on endothelial cells. Curr. Opin. Cell Biol. 20:525-532. http://dx.doi.org/10.1016/j.ceb.2008.04.003

Alon, R., and Z. Shulman. 2011. Chemokine triggered integrin activation and actin remodeling events guiding lymphocyte migration across vascular barriers. Exp. Cell Res. 317:632-641. http://dx.doi.org/10 .1016/j.yexcr.2010.12.007

Balch, C.M., A.C. Buzaid, S.J. Soong, M.B. Atkins, N. Cascinelli, D.G. Coit, I.D. Fleming, J.E. Gershenwald, A. Houghton Jr., J.M. Kirkwood, et al. 2001. Final version of the American Joint Committee on Cancer staging system for cutaneous melanoma. J. Clin. Oncol. 19:3635-3648.

Ben-Baruch, A. 2008. Organ selectivity in metastasis: regulation by chemokines and their receptors. Clin. Exp. Metastasis. 25:345-356. http:// dx.doi.org/10.1007/s10585-007-9097-3

Braun, A., T. Worbs, G.L. Moschovakis, S. Halle, K. Hoffmann, J. Bölter, A. Münk, and R. Förster. 2011. Afferent lymph-derived T cells and DCs use different chemokine receptor CCR7-dependent routes for 
entry into the lymph node and intranodal migration. Nat. Immunol. 12:879-887. http://dx.doi.org/10.1038/ni.2085

Burger, J.A., M. Burger, and T.J. Kipps. 1999. Chronic lymphocytic leukemia B cells express functional CXCR 4 chemokine receptors that mediate spontaneous migration beneath bone marrow stromal cells. Blood. 94:3658-3667.

Cabioglu, N., M.S. Yazici, B. Arun, K.R. Broglio, G.N. Hortobagyi, J.E. Price, and A. Sahin. 2005. CCR7 and CXCR4 as novel biomarkers predicting axillary lymph node metastasis in T1 breast cancer. Clin. Cancer Res. 11:5686-5693. http://dx.doi.org/10.1158/1078-0432. CCR-05-0014

Carr, I. 1983. Lymphatic metastasis. Cancer Metastasis Rev. 2:307-317. http://dx.doi.org/10.1007/BF00048483

Carr, I., M. Levy, K. Orr, and J. Bruni. 1985. Lymph node metastasis and cell movement: ultrastructural studies on the rat 13762 mammary carcinoma and Walker carcinoma. Clin. Exp. Metastasis. 3:125-139. http:// dx.doi.org/10.1007/BF01758961

Chensue, S.W., N.W. Lukacs, T.Y. Yang, X. Shang, K.A. Frait, S.L. Kunkel, T. Kung, M.T. Wiekowski, J.A. Hedrick, D.N. Cook, et al. 2001. Aberrant in vivo $\mathrm{T}$ helper type 2 cell response and impaired eosinophil recruitment in CC chemokine receptor 8 knockout mice. J. Exp. Med. 193:573-584. http://dx.doi.org/10.1084/jem.193.5.573

Cohen, J.N., C.J. Guidi, E.F. Tewalt, H. Qiao, S.J. Rouhani, A. Ruddell, A.G. Farr, K.S. Tung, and V.H. Engelhard. 2010. Lymph node-resident lymphatic endothelial cells mediate peripheral tolerance via Aire-independent direct antigen presentation. J. Exp. Med. 207:681-688. http:// dx.doi.org/10.1084/jem.20092465

Condeelis, J., and J.E. Segall. 2003. Intravital imaging of cell movement in tumours. Nat. Rev. Cancer. 3:921-930. http://dx.doi.org/10.1038/nrc1231

D’Ambrosio, D., A. Iellem, R. Bonecchi, D. Mazzeo, S. Sozzani, A. Mantovani, and F. Sinigaglia. 1998. Selective up-regulation of chemokine receptors CCR 4 and CCR 8 upon activation of polarized human type 2 Th cells. J. Immunol. 161:5111-5115.

Dadiani, M., V. Kalchenko, A. Yosepovich, R. Margalit, Y. Hassid, H. Degani, and D. Seger. 2006. Real-time imaging of lymphogenic metastasis in orthotopic human breast cancer. Cancer Res. 66:8037-8041. http://dx.doi.org/10.1158/0008-5472.CAN-06-0728

Das, S., and M. Skobe. 2008. Lymphatic vessel activation in cancer. Ann. N. Y. Acad. Sci. 1131:235-241. http://dx.doi.org/10.1196/annals.1413.021

Das, S., D.S. Ladell, S. Podgrabinska, V. Ponomarev, C. Nagi, J.T. Fallon, and M. Skobe. 2010. Vascular endothelial growth factor-C induces lymphangitic carcinomatosis, an extremely aggressive form of lung metastases. Cancer Res. 70:1814-1824. http://dx.doi.org/10.1158/00085472.CAN-09-3675

Debes, G.F., C.N. Arnold, A.J. Young, S. Krautwald, M. Lipp, J.B. Hay, and E.C. Butcher. 2005. Chemokine receptor CCR7 required for T lymphocyte exit from peripheral tissues. Nat. Immunol. 6:889-894. http://dx.doi.org/10.1038/ni1238

Dewar, D.J., B. Newell, M.A. Green, A.P. Topping, B.W. Powell, and M.G. Cook. 2004. The microanatomic location of metastatic melanoma in sentinel lymph nodes predicts nonsentinel lymph node involvement. J. Clin. Oncol. 22:3345-3349. http://dx.doi.org/10.1200/JCO.2004.12.177

Düllmann, J., E.J. Van Damme, W.J. Peumans, M. Ziesenitz, and U. Schumacher. 2002. Lectin histochemistry of the rat lymph node: visualisation of stroma, blood vessels, sinuses, and macrophages. A contribution to the concept of an immune accessory role of sinus-lining endothelia. Acta Histochem. 104:77-83. http://dx.doi.org/10.1078/0065-1281-00616

Ebert, L.M., S. Meuter, and B. Moser. 2006. Homing and function of human skin gammadelta $\mathrm{T}$ cells and NK cells: relevance for tumor surveillance. J. Immunol. 176:4331-4336.

Entenberg, D., J. Wyckoff, B. Gligorijevic, E.T. Roussos, V.V. Verkhusha, J.W. Pollard, and J. Condeelis. 2011. Setup and use of a two-laser multiphoton microscope for multichannel intravital fluorescence imaging. Nat. Protoc. 6:1500-1520. http://dx.doi.org/10.1038/ nprot.2011.376

Förster, R., A. Braun, and T. Worbs. 2012. Lymph node homing of T cells and dendritic cells via afferent lymphatics. Trends Immunol. 33:271-280. http://dx.doi.org/10.1016/j.it.2012.02.007
Fossum, S. 1980. The architecture of rat lymph nodes. IV. Distribution of ferritin and colloidal carbon in the draining lymph nodes after foot-pad injection. Scand. J. Immunol. 12:433-441. http://dx.doi.org/10.1111/ j.1365-3083.1980.tb00087.x

Gombert, M., M.C. Dieu-Nosjean, F. Winterberg, E. Bünemann, R.C. Kubitza, L. Da Cunha, A. Haahtela, S. Lehtimäki, A. Müller, J. Rieker, et al. 2005. CCL1-CCR8 interactions: an axis mediating the recruitment of $\mathrm{T}$ cells and Langerhans-type dendritic cells to sites of atopic skin inflammation. J. Immunol. 174:5082-5091.

Goya, I., J. Gutiérrez, R. Varona, L. Kremer, A. Zaballos, and G. Márquez. 1998. Identification of CCR 8 as the specific receptor for the human beta-chemokine I-309: cloning and molecular characterization of murine CCR8 as the receptor for TCA-3. J. Immunol. 160:1975-1981.

Greene, F.L., D.L. Page, I.D. Fleming, A. Fritz, D.M. Balch, D.G. Haller, M. Morrow., eds. 2002. AJCC Cancer Staging Manual, 6th Ed. SpringerVerlag, New York. 435 pp.

Gretz, J.E., C.C. Norbury, A.O. Anderson, A.E. Proudfoot, and S. Shaw. 2000. Lymph-borne chemokines and other low molecular weight molecules reach high endothelial venules via specialized conduits while a functional barrier limits access to the lymphocyte microenvironments in lymph node cortex. J. Exp. Med. 192:1425-1440. http://dx.doi.org/10 $.1084 / \mathrm{jem} .192 .10 .1425$

Gunn, M.D., K.Tangemann, C.Tam,J.G. Cyster, S.D. Rosen, and L.T.Williams. 1998. A chemokine expressed in lymphoid high endothelial venules promotes the adhesion and chemotaxis of naive T lymphocytes. Proc. Natl. Acad. Sci. USA. 95:258-263. http://dx.doi.org/10.1073/pnas.95.1.258

Haque, N.S., J.T. Fallon, J.J. Pan, M.B. Taubman, and P.C. Harpel. 2004. Chemokine receptor-8 (CCR8) mediates human vascular smooth muscle cell chemotaxis and metalloproteinase-2 secretion. Blood. 103:12961304. http://dx.doi.org/10.1182/blood-2002-05-1480

Hayashi, K., P. Jiang, K. Yamauchi, N. Yamamoto, H. Tsuchiya, K. Tomita, A.R. Moossa, M. Bouvet, and R.M. Hoffman. 2007. Realtime imaging of tumor-cell shedding and trafficking in lymphatic channels. Cancer Res. 67:8223-8228. http://dx.doi.org/10.1158/0008-5472. CAN-07-1237

Houshmand, P., and A. Zlotnik. 2003. Therapeutic applications in the chemokine superfamily. Curr. Opin. Chem. Biol. 7:457-460. http://dx.doi .org/10.1016/S1367-5931(03)00086-3

Ishigami, S., S. Natsugoe, A. Nakajo, K. Tokuda, Y. Uenosono, T. Arigami, M. Matsumoto, H. Okumura, S. Hokita, and T. Aikou. 2007. Prognostic value of CCR7 expression in gastric cancer. Hepatogastroenterology. 54:1025-1028.

Islam, S.A., D.S. Chang, R.A. Colvin, M.H. Byrne, M.L. McCully, B. Moser, S.A. Lira, I.F. Charo, and A.D. Luster. 2011. Mouse CCL8, a CCR 8 agonist, promotes atopic dermatitis by recruiting IL-5+ T(H)2 cells. Nat. Immunol. 12:167-177. http://dx.doi.org/10.1038/ni.1984

Jamieson, T., D.N. Cook, R.J. Nibbs, A. Rot, C. Nixon, P. McLean, A. Alcami, S.A. Lira, M. Wiekowski, and G.J. Graham. 2005. The chemokine receptor D6 limits the inflammatory response in vivo. Nat. Immunol. 6:403-411. http://dx.doi.org/10.1038/ni1182

Jia, L., Z. Xie, J. Zheng, L. Liu, Y. He, F. Liu, and Y. He. 2012. Morphological studies of lymphatic labyrinths in the rat mesenteric lymph node. Anat. Rec. (Hoboken). 295:1291-1301. http://dx.doi.org/10.1002/ar.22509

Junt, T., E.A. Moseman, M. Iannacone, S. Massberg, P.A. Lang, M. Boes, K. Fink, S.E. Henrickson, D.M. Shayakhmetov, N.C. Di Paolo, et al. 2007. Subcapsular sinus macrophages in lymph nodes clear lymphborne viruses and present them to antiviral B cells. Nature. 450:110-114 http://dx.doi.org/10.1038/nature06287

Kerjaschki, D., H.M. Regele, I. Moosberger, K. Nagy-Bojarski, B. Watschinger, A. Soleiman, P. Birner, S. Krieger, A. Hovorka, G. Silberhumer, et al. 2004. Lymphatic neoangiogenesis in human kidney transplants is associated with immunologically active lymphocytic infiltrates. J. Am. Soc. Nephrol. 15:603-612. http://dx.doi.org/10.1097/01 .ASN.0000113316.52371.2E

Li, J.L., C.C. Goh, J.L. Keeble, J.S. Qin, B. Roediger, R. Jain, Y. Wang, W.K. Chew, W. Weninger, and L.G. Ng. 2012. Intravital multiphoton imaging of immune responses in the mouse ear skin. Nat. Protoc. 7:221-234. http://dx.doi.org/10.1038/nprot.2011.438 
Lindquist, R.L., G. Shakhar, D. Dudziak, H. Wardemann, T. Eisenreich, M.L. Dustin, and M.C. Nussenzweig. 2004. Visualizing dendritic cell networks in vivo. Nat. Immunol. 5:1243-1250. http://dx.doi.org/ 10.1038/ni1139

Louahed, J., S. Struyf, J.B. Demoulin, M. Parmentier, J. Van Snick, J. Van Damme, and J.C. Renauld. 2003. CCR8-dependent activation of the RAS/MAPK pathway mediates anti-apoptotic activity of I-309/CCL1 andvMIP-I.Eur.J.Immunol.33:494-501.http://dx.doi.org/ 10.1002/immu.200310025

Luo, Y., J. Laning, S. Devi, J. Mak, T.J. Schall, and M.E. Dorf. 1994. Biologic activities of the murine beta-chemokine TCA3. J. Immunol. 153:4616-4624.

Lüttichau, H.R., J. Stine, T.P. Boesen, A.H. Johnsen, D. Chantry, J. Gerstoft, and T.W. Schwartz. 2000. A highly selective CC chemokine receptor (CCR) 8 antagonist encoded by the poxvirus molluscum contagiosum. J. Exp. Med. 191:171-180. http://dx.doi.org/10.1084/jem.191.1.171

Lüttichau, H.R., J. Gerstoft, and T.W. Schwartz. 2001. MC148 encoded by human molluscum contagiosum poxvirus is an antagonist for human but not murine CCR8. J. Leukoc. Biol. 70:277-282.

Martens, J.H., J. Kzhyshkowska, M. Falkowski-Hansen, K. Schledzewski, A. Gratchev, U. Mansmann, C. Schmuttermaier, E. Dippel, W. Koenen, F. Riedel, et al. 2006. Differential expression of a gene signature for scavenger/lectin receptors by endothelial cells and macrophages in human lymph node sinuses, the primary sites of regional metastasis. J. Pathol. 208:574-589. http://dx.doi.org/10.1002/path.1921

Mashino, K., N. Sadanaga, H. Yamaguchi, F. Tanaka, M. Ohta, K. Shibuta, H. Inoue, and M. Mori. 2002. Expression of chemokine receptor CCR7 is associated with lymph node metastasis of gastric carcinoma. Cancer Res. 62:2937-2941.

Miller, M.D., and M.S. Krangel. 1992. The human cytokine I-309 is a monocyte chemoattractant. Proc. Natl. Acad. Sci. USA. 89:2950-2954. http://dx.doi.org/10.1073/pnas.89.7.2950

Miller, M.D., S. Hata, R. De Waal Malefyt, and M.S. Krangel. 1989 A novel polypeptide secreted by activated human $\mathrm{T}$ lymphocytes. J. Immunol. 143:2907-2916.

Morton, D.L., J.F. Thompson, A.J. Cochran, N. Mozzillo, R. Elashoff, R. Essner, O.E. Nieweg, D.F. Roses, H.J. Hoekstra, C.P. Karakousis, et al; MSLT Group. 2006. Sentinel-node biopsy or nodal observation in melanoma. N. Engl. J. Med. 355:1307-1317. http://dx.doi.org/10 .1056/NEJMoa060992

Müller, A., B. Homey, H. Soto, N. Ge, D. Catron, M.E. Buchanan, T. McClanahan, E. Murphy, W. Yuan, S.N. Wagner, et al. 2001. Involvement of chemokine receptors in breast cancer metastasis. Nature. 410:50-56. http://dx.doi.org/10.1038/35065016

Nathanson, S.D. 2003. Insights into the mechanisms of lymph node metastasis. Cancer. 98:413-423. http://dx.doi.org/10.1002/cncr.11464

Ohtani, O., and Y. Ohtani. 2008. Structure and function of rat lymph nodes. Arch. Histol. Cytol. 71:69-76. http://dx.doi.org/10.1679/aohc.71.69

Ohtani, O., Y. Ohtani, C.J. Carati, and B.J. Gannon. 2003. Fluid and cellular pathways of rat lymph nodes in relation to lymphatic labyrinths and Aquaporin-1 expression. Arch. Histol. Cytol. 66:261-272. http://dx.doi .org/10.1679/aohc.66.261

Pape, K.A., D.M. Catron, A.A. Itano, and M.K. Jenkins. 2007. The humoral immune response is initiated in lymph nodes by B cells that acquire soluble antigen directly in the follicles. Immunity. 26:491-502. http://dx.doi.org/10.1016/j.immuni.2007.02.011

Pawlik, T.M., M.I. Ross, J.F. Thompson, A.M. Eggermont, and J.E. Gershenwald. 2005. The risk of in-transit melanoma metastasis depends on tumor biology and not the surgical approach to regional lymph nodes. J. Clin. Oncol. 23:4588-4590. http://dx.doi.org/10.1200/JCO.2005.12.245

Pepper, M.S., and M. Skobe. 2003. Lymphatic endothelium: morphological, molecular and functional properties. J. Cell Biol. 163:209-213. http:// dx.doi.org/10.1083/jcb.200308082

Pfeiffer, F., V. Kumar, S. Butz, D. Vestweber, B.A. Imhof, J.V. Stein, and B. Engelhardt. 2008. Distinct molecular composition of blood and lymphatic vascular endothelial cell junctions establishes specific functional barriers within the peripheral lymph node. Eur. J. Immunol. 38:21422155. http://dx.doi.org/10.1002/eji.200838140
Phan, T.G., I. Grigorova, T. Okada, and J.G. Cyster. 2007. Subcapsular encounter and complement-dependent transport of immune complexes by lymph node B cells. Nat. Immunol. 8:992-1000. http://dx.doi.org/10 $.1038 /$ ni1494

Podgrabinska, S., P. Braun, P. Velasco, B. Kloos, M.S. Pepper, and M. Skobe. 2002. Molecular characterization of lymphatic endothelial cells. Proc. Natl. Acad. Sci. USA. 99:16069-16074. http://dx.doi.org/10.1073/ pnas. 242401399

Podgrabinska, S., O. Kamalu, L. Mayer, M. Shimaoka, H. Snoeck, G.J. Randolph, and M. Skobe. 2009. Inflamed lymphatic endothelium suppresses dendritic cell maturation and function via Mac-1/ICAM-1dependent mechanism.J. Immunol. 183:1767-1779. http://dx.doi.org/10 $.4049 /$ jimmunol.0802167

Qu, C., E.W. Edwards, F. Tacke, V. Angeli, J. Llodrá, G. Sanchez-Schmitz, A. Garin, N.S. Haque, W. Peters, N. van Rooijen, et al. 2004. Role of CCR 8 and other chemokine pathways in the migration of monocytederived dendritic cells to lymph nodes. J. Exp. Med. 200:1231-1241. http://dx.doi.org/10.1084/jem.20032152

Roberts, N., B. Kloos, M. Cassella, S. Podgrabinska, K. Persaud, Y. Wu, B. Pytowski, and M. Skobe. 2006. Inhibition of VEGFR-3 activation with the antagonistic antibody more potently suppresses lymph node and distant metastases than inactivation of VEGFR-2. Cancer Res. 66:26502657. http://dx.doi.org/10.1158/0008-5472.CAN-05-1843

Roos, R.S., M. Loetscher, D.F. Legler, I. Clark-Lewis, M. Baggiolini, and B. Moser. 1997. Identification of CCR8, the receptor for the human CC chemokine I-309. J. Biol. Chem. 272:17251-17254. http://dx.doi.org/ 10.1074/jbc.272.28.17251

Roozendaal, R., T.R. Mempel, L.A. Pitcher, S.F. Gonzalez, A Verschoor, R.E. Mebius, U.H. von Andrian, and M.C. Carroll. 2009. Conduits mediate transport of low-molecular-weight antigen to lymph node follicles. Immunity. 30:264-276. http://dx.doi.org/ 10.1016/j.immuni.2008.12.014

Roussos, E.T., J.S. Condeelis, and A. Patsialou. 2011. Chemotaxis in cancer. Nat. Rev. Cancer. 11:573-587. http://dx.doi.org/10.1038/nrc3078

Ruckes, T., D. Saul, J. Van Snick, O. Hermine, and R. Grassmann. 2001. Autocrine antiapoptotic stimulation of cultured adult T-cell leukemia cells by overexpression of the chemokine I-309. Blood. 98:1150-1159. http://dx.doi.org/10.1182/blood.V98.4.1150

Sainte-Marie, G., F.S. Peng, and C. Bélisle. 1982. Overall architecture and pattern of lymph flow in the rat lymph node. Am. J. Anat. 164:275-309. http://dx.doi.org/10.1002/aja.1001640402

Schaerli, P., L. Ebert, K. Willimann, A. Blaser, R.S. Roos, P. Loetscher, and B. Moser. 2004. A skin-selective homing mechanism for human immune surveillance T cells. J. Exp. Med. 199:1265-1275. http://dx.doi.org/10 $.1084 /$ jem.20032177

Schumann, K., T. Lämmermann, M. Bruckner, D.F. Legler, J. Polleux, J.P. Spatz, G. Schuler, R. Förster, M.B. Lutz, L. Sorokin, and M. Sixt. 2010. Immobilized chemokine fields and soluble chemokine gradients cooperatively shape migration patterns of dendritic cells. Immunity. 32:703713. http://dx.doi.org/10.1016/j.immuni.2010.04.017

Shafie, S.M., and L.A. Liotta. 1980. Formation of metastasis by human breast carcinoma cells (MCF-7) in nude mice. Cancer Lett. 11:81-87. http:// dx.doi.org/10.1016/0304-3835(80)90097-X

Shields, J.D., M.S. Emmett, D.B. Dunn, K.D. Joory, L.M. Sage, H. Rigby, P.S. Mortimer, A. Orlando, J.R. Levick, and D.O. Bates. 2007a. Chemokine-mediated migration of melanoma cells towards lymphatics-a mechanism contributing to metastasis. Oncogene. 26:2997-3005. http://dx.doi.org/10.1038/sj.onc.1210114

Shields, J.D., M.E. Fleury, C. Yong, A.A. Tomei, G.J. Randolph, and M.A. Swartz. 2007b. Autologous chemotaxis as a mechanism of tumor cell homing to lymphatics via interstitial flow and autocrine CCR7 signaling. Cancer Cell. 11:526-538. http://dx.doi.org/10.1016/j.ccr .2007 .04 .020

Skobe, M., L.M. Hamberg, T. Hawighorst, M. Schirner, G.L. Wolf, K. Alitalo, and M. Detmar. 2001a. Concurrent induction of lymphangiogenesis, angiogenesis, and macrophage recruitment by vascular endothelial growth factor-C in melanoma. Am. J. Pathol. 159:893-903. http://dx.doi.org/10.1016/S0002-9440(10)61765-8 
Skobe, M., T. Hawighorst, D.G. Jackson, R. Prevo, L. Janes, P. Velasco, L. Riccardi, K. Alitalo, K. Claffey, and M. Detmar. 2001b. Induction of tumor lymphangiogenesis by VEGF-C promotes breast cancer metastasis. Nat. Med. 7:192-198. http://dx.doi.org/10.1038/84643

Soler, D., T.R. Chapman, L.R. Poisson, L. Wang, J. Cote-Sierra, M. Ryan, A. McDonald, S. Badola, E. Fedyk, A.J. Coyle, et al. 2006. CCR8 expression identifies CD4 memory $\mathrm{T}$ cells enriched for FOXP3+ regulatory and Th2 effector lymphocytes. J. Immunol. 177:6940-6951.

Soule, H.D., T.M. Maloney, S.R. Wolman, W.D. Peterson Jr., R. Brenz, C.M. McGrath, J. Russo, R.J. Pauley, R.F. Jones, and S.C. Brooks. 1990. Isolation and characterization of a spontaneously immortalized human breast epithelial cell line, MCF-10. Cancer Res. 50:6075-6086.

Swartz, M.A. 2001. The physiology of the lymphatic system. Adv. Drug Deliv. Rev. 50:3-20. http://dx.doi.org/10.1016/S0169-409X(01)00150-8

Szakal, A.K., K.L. Holmes, and J.G. Tew. 1983. Transport of immune complexes from the subcapsular sinus to lymph node follicles on the surface of nonphagocytic cells, including cells with dendritic morphology. $J$. Immunol. 131:1714-1727.

Tal, O., H.Y. Lim, I. Gurevich, I. Milo, Z. Shipony, L.G. Ng, V. Angeli, and G. Shakhar. 2011. DC mobilization from the skin requires docking to immobilized CCL21 on lymphatic endothelium and intralymphatic crawling. J. Exp. Med. 208:2141-2153. http://dx.doi.org/10.1084/jem.20102392

Tamgüney, G., J. Van Snick, and H. Fickenscher. 2004. Autocrine stimulation of rhadinovirus-transformed T cells by the chemokine CCL1/I-309. Oncogene. 23:8475-8485. http://dx.doi.org/10.1038/sj.onc.1207903

Tiffany, H.L., L.L. Lautens, J.L. Gao, J. Pease, M. Locati, C. Combadiere, W. Modi, T.I. Bonner, and P.M. Murphy. 1997. Identification of CCR8: a human monocyte and thymus receptor for the CC chemokine I-309. J. Exp. Med. 186:165-170. http://dx.doi.org/10.1084/jem.186.1.165

Tsopelas, C., and R. Sutton. 2002. Why certain dyes are useful for localizing the sentinel lymph node. J. Nucl. Med. 43:1377-1382

van Deurzen, C.H., P.J. Borgstein, and P.J. van Diest. 2008. In-transit lymph node metastases in breast cancer: a possible source of local recurrence after
Sentinel Node procedure. J. Clin. Pathol. 61:1314-1316. http://dx.doi .org/10.1136/jcp.2008.059600

Van Snick, J., F. Houssiau, P. Proost, J. Van Damme, and J.C. Renauld. 1996. I-309/T cell activation gene-3 chemokine protects murine T cell lymphomas against dexamethasone-induced apoptosis. J. Immunol. 157: 2570-2576.

von Andrian, U.H., and T.R. Mempel. 2003. Homing and cellular traffic in lymph nodes. Nat. Rev. Immunol.3:867-878. http://dx.doi.org/10.1038/ nri1222

Vona, G., A. Sabile, M. Louha, V. Sitruk, S. Romana, K. Schütze, F. Capron, D. Franco, M. Pazzagli, M. Vekemans, et al. 2000. Isolation by size of epithelial tumor cells : a new method for the immunomorphological and molecular characterization of circulatingtumor cells. Am.J.Pathol.156:57-63. http://dx.doi.org/10.1016/S0002-9440(10) 64706-2

Walen, K.H., and M.R. Stampfer. 1989. Chromosome analyses of human mammary epithelial cells at stages of chemical-induced transformation progression to immortality. Cancer Genet. Cytogenet. 37:249-261. http://dx.doi.org/10.1016/0165-4608(89)90056-3

Wiley, H.E., E.B. Gonzalez, W. Maki, M.T. Wu, and S.T. Hwang. 2001. Expression of CC chemokine receptor-7 and regional lymph node metastasis of B16 murine melanoma. J. Natl. Cancer Inst. 93:1638-1643. http://dx.doi.org/10.1093/jnci/93.21.1638

Wyckoff, J., B. Gligorijevic, D. Entenberg, J. Segall, and J. Condeelis. 2011. High-resolution multiphoton imaging of tumors in vivo. Cold Spring Harb Protoc. 2011:1167-1184.

Zakut, R., R. Perlis, S. Eliyahu, Y. Yarden, D. Givol, S.D. Lyman, and R. Halaban. 1993. KIT ligand (mast cell growth factor) inhibits the growth of KIT-expressing melanoma cells. Oncogene. 8:2221-2229.

Zingoni, A., H. Soto, J.A. Hedrick, A. Stoppacciaro, C.T. Storlazzi, F. Sinigaglia, D. D'Ambrosio, A. O'Garra, D. Robinson, M. Rocchi, et al. 1998. The chemokine receptor CCR 8 is preferentially expressed in Th2 but not Th1 cells. J. Immunol. 161:547-551. 